\title{
Geology and petrography of paleoproterozoic granitoid rocks from Uatumã- Anauá Domain, central region of Guyana Shield, southeastern Roraima, Brazil
}

\author{
Marcelo Esteves Almeida ${ }^{1,2}$ \& Moacir José Buenano Macambira ${ }^{2}$
}

\begin{abstract}
Regional mapping carried out in the Uatumã-Anauá Domain (UAD), Guyana Shield, southeastern Roraima (Brazil), has showed widespread calc-alkaline granitic to alkaline magmatism and local peraluminous granites. These granitoid rocks are distributed into several magmatic associations with different Paleoproterozoic $(1.97-1.89 \mathrm{Ga})$ ages, structural and geochemical affinities. In this paper, detailed mapping and petrographic studies have distinguished two main subdomains in UAD. In the northern UAD, the Martins Pereira I-type, calc-alkaline granitoid rocks and Serra Dourada S-type granite (1.97-1.96 Ga) are deformed and affected by NE-SW and E-W shear zones. Basement inliers $(2.03 \mathrm{Ga})$ crop out to the northeastern part of this area, and are formed by rocks from metavolcano-sedimentary sequence (Cauarane Group) and TTG-like calc-alkaline association (Anauá Complex). Younger and undeformed (with local discrete NE-SW shear zones) Igarapé Azul and Caroebe granites (I-type, calc-alkaline Água Branca suite) crop out in the southern UAD. A-type granites such as Moderna $(1.81 \mathrm{Ga})$ and Mapuera $(1.87 \mathrm{Ga})$ plutons, cross cut both areas of UAD. Gold mineralization is observed in the Martins Pereira granitoid rocks (northern UAD), alluvial columbite-tantalite is related to the Igarapé Azul granitoid rocks (southern UAD), and amethyst is associated to pegmatites of the Moderna A-type granites.
\end{abstract}

Keywords: Granitoid rocks, Petrography, Roraima, Guyana Shield, Paleoproterozoic.

Resumo Geologia e petrografia dos granitóides Paleoproterozóicos do domínio Uatumã-Anauá, região central do Escudo das Guianas, sudeste de Roraima, Brasil. Mapeamentos geológicos na escala regional identificaram no Domínio Uatumã-Anauá (DUA), sudeste do Estado de Roraima (Brasil), porção central do Escudo das Güianas, um amplo domínio de granitóides cálcio-alcalinos a alcalinos, além de subordinados granitos peraluminosos de natureza crustal. Estes granitóides estão distribuídos em diferentes associações magmáticas com idades, estilos de deformação e afinidades químicas distintos. Neste trabalho, mapeamento geológico de maior detalhe, apoiado por estudo petrográfico, propiciou a distinção de algumas dessas associações que ocorrem em duas áreas distintas (norte e sul). Os granitóides deformados do setor norte do DUA (1,97-1,96 Ga) são representados pelos granitos Martins Pereira (do tipo I, cálcio-alcalino) e Serra Dourada (do tipo $\mathrm{S}$ ), e em geral estão associados a amplas zonas de cisalhamento dúctil destrais de direção NE-SW a E-W. Ainda no setor norte do DUA, remanescentes do embasamento (2,03 Ga) são representados por sucessão metavulcanossedimentar (Grupo Cauarane) e associação granítica do tipo TTG (Complexo Anauá). Os granitóides do setor sul do DUA (1,90-1,89 Ga), que incluem os granitos lgarapé Azul e Caroebe da suíte Água Branca (tipo I, cálcio-alcalino), são isotrópicos e estão afetados apenas localmente por zonas de cisalhamento NE-SW. Dois eventos graníticos tipo-A intrusivos ocorrem no DUA: granitóides Moderna ( $\sim 1,81 \mathrm{Ga})$ e Mapuera-Abonari $(\sim 1,87 \mathrm{Ga})$. Ocorrências primárias de ouro estão hospedadas nos granitóides Martins Pereira (setor norte), ocorrências aluvionares de Nb-Ta são encontradas no granito Igarapé Azul (setor sul), enquanto que pegmatitos com ametista estão presentes em corpos relacionados ao granito Moderna.

Palavras-chave: Granitóides, Petrografia, Roraima, Escudos das Guianas, Paleoproterozóico.

INTRODUCTION Calc-alkaline I-type granitoid rocks, including aluminous to alkaline A-type granites, charnockitic rocks and minor S-type granites (CPRM $1999,2000)$ are widespread in the central portion of the Guyana Shield, southeastern Roraima State, Brazil (Fig. 1). The polycyclic geological setting in the area results in low- and high-grade terranes with complex tectonic regime. In this area there is overprinting of events whereas the relationship between granitogenesis and the major Transamazonian orogeny is not well es- tablished. This uncertain geological picture is mainly resulted from scarce geological mapping.

Nevertheless, recent regional geological mapping supported by lithostructural and geochronology (Fig. 1; CPRM 2006, modified from Reis et al. 2003) outlined different lithological associations in Roraima State related with four domains is proposed:

(1) The Surumu domain (north-northeastern Roraima) exhibits WNW-ESE and E-W structural trends. In this domain calc-alkaline granites and volcanic rocks (1.98-

1 - CPRM, Geological Survey of Brazil, Manaus, Amazonas, Brazil. E-mail: marcelo almeida@ma.cprm.gov.br

2 - Isotope Geology Laboratory, Center of Geosciences, Federal University of Pará, Belém, Pará, Brazil. 


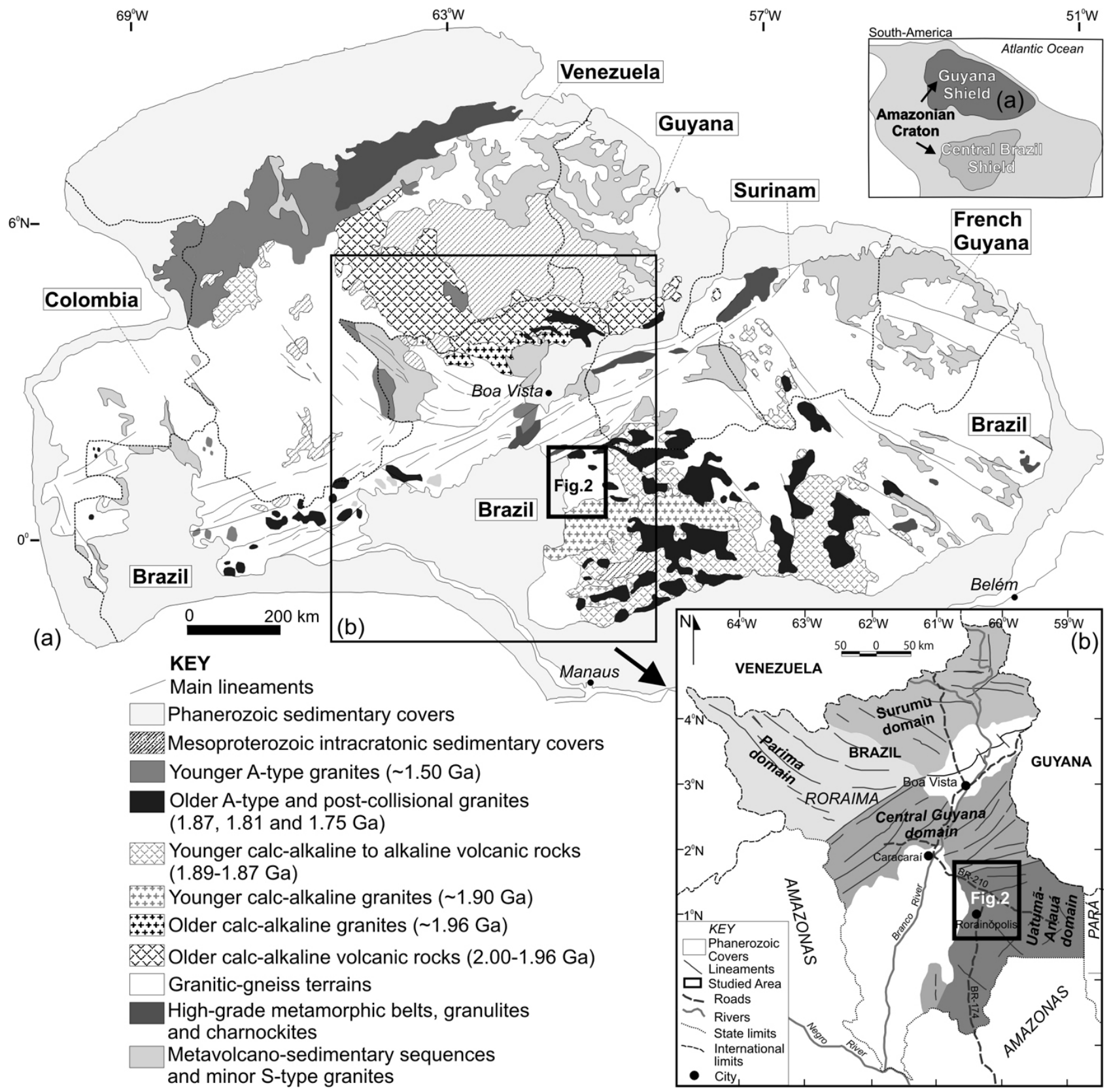

Figure 1 - Geological sketch of (a) Guyana Shield (after Gibbs and Barron 1993) and location of the studied area showing the (b) southeast of Roraima State and tectonic boundaries, including the lithostructural domains (after Reis and Fraga 2000, Reis et al. 2003 modified by CPRM 2006). For studied area details see figure 2 .

$1.95 \mathrm{Ga})$ show local deformation at greenschist-facies. Cratonic sedimentary sequences $(1.87-1.78 \mathrm{Ga})$ partly cover the volcanic rocks. Late to post-Transamazonian supracrustal rocks (2.03-1.97 Ga?) are exposed only in the southwestern part of this domain.

(2) The Central Guyana domain (central Roraima) shows NE-SW structural trends, and amphibolite-facies gneiss predominates over granulite-facies rocks (1.96$1.93 \mathrm{Ga}$ ). A typical Mesoproterozoic Anorthosite-Mangerite-Granite association (1.56-1.53 Ga) intrudes the older units.

(3) The Parima domain (west-northwestern Roraima) includes extensive late to post-Transamazonian granite- greenstone terranes and has predominantly NW-SE to E-W foliation. Granitic plutons and volcanic rocks, similar to those exposed in the Surumu domain, are subordinated. Batholiths and stocks of rapakivi granite $(1.55 \mathrm{Ga})$ as well as sedimentary covers are also present.

(4) The Uatumã-Anauá domain (southeastern Roraima, northeastern Amazonas and northwestern Pará) comprises widespread granite magmatism $(2.03-1.81 \mathrm{Ga})$ and supracrustal rocks with NW-SE (and NE-SW) foliations and deformed at greenschist to amphibolitefacies conditions.

The studied area encompasses mainly calc-al- 
kaline granitoid rocks intrusive in the Uatumã-Anauá domain (UAD), such as Martins Pereira (Almeida et al. 2002), Igarapé Azul (Faria et al. 1999, Almeida et al. 2002) and Caroebe granites. Locally, they host ore mineral like gold and columbite-tantalite.

In this paper, we summarize field and petrographic studies and propose a new geological map based on the groups of granitoid rocks and related mineralizations, for the northwestern part of the UAD, providing new insights about the tectonic significance of the granitoid rocks in southeastern Roraima.

GEOLOGICAL SETTING The Uatumã-Anauá domain (UAD, CPRM 2006 modified from Reis and Fraga 2000, Reis et al. 2003), also named as northern
Tapajós-Parima belt (Uaimiri domain, Santos et al. 2000) or northern Ventuari-Tapajós province (Tassinari and Macambira 1999), is characterized by metamorphic basement and intrusive granitoid rocks (Fig. 2).

According to Faria et al. (2002), in the northern Uatumã-Anauá domain (NUAD) the basement rocks comprise an island arc setting (Anauá arc) formed by TTG-like metagranitoid rocks and orthogneiss with metamafic to metaultramafic enclaves (Anauá Complex), and inliers of metavolcano-sedimentary rocks (Cauarane Group). The basement rocks occur in the northern part of the studied area (Fig. 2), and is intruded by S-type (Serra Dourada) and I-type calc-alkaline (Martins Pereira) granites, which correspond to the 2.03 to $1.96 \mathrm{Ga}$ Martins Pereira-Anauá granitic terrane

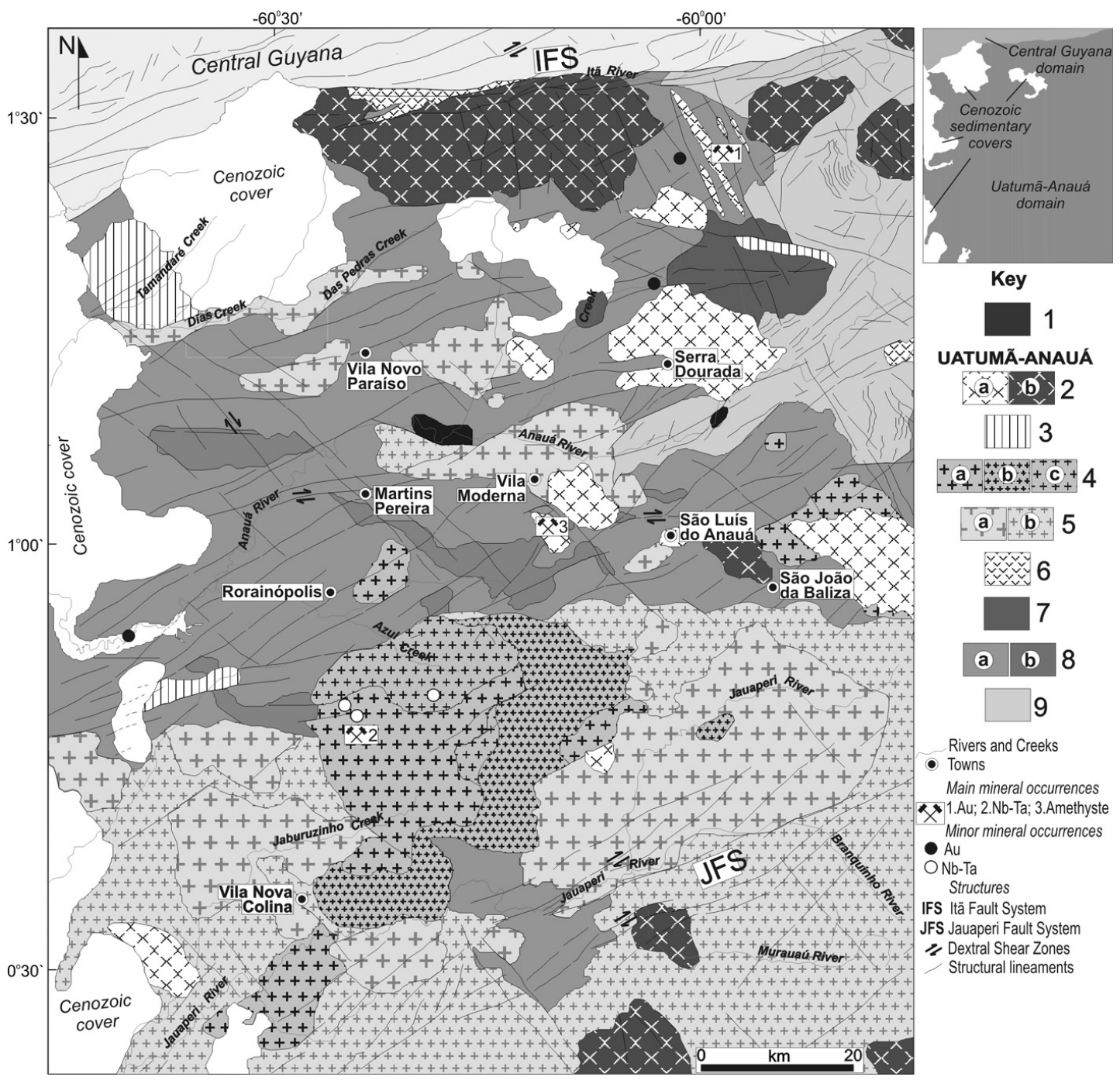

Figure 2 - Geological sketch map of southeastern Roraima (modified from Almeida et al. 2002 and CPRM 2000). 1. Undiscriminated plutonic mafic rocks, 2. A-type granites: a) Moderna (1.81 Ga), b) Mapuera (1.87 Ga); 3. Santa Maria enderbite, Tamandaré charnockite and undiscriminated charnockitoids; 4. Igarapé Azul granites (1.89 Ga): a) Vila Catarina, b) Estrela Guia, and c) Saramandaia facies; 5. Caroebe granites (1.90-1.89 Ga): a) Jaburuzinho, b) Alto Alegre facies; 6. Calc-alkaline volcanic rocks (1.89 Ga); 7. S-type (cordierite) Serra Dourada granite (1.96 Ga), 8. High-K calc-alkaline Martins Pereira granitoid rocks (1.97 Ga): a) normal to b) high U, Th, K contents, 9. Metavolcano-sedimentary sequence (Cauarane Group related: <2.03 Ga?) and TTG calc-alkaline association (Anauá Complex: $2.03 \mathrm{Ga}$ ). 
(Almeida et al. 2002).

In the southern part of the Uatumã-Anauá domain (SUAD, Fig. 2), the Caroebe and Igarapé Azul calc-alkaline granitoid rocks are $\sim 70$ M.y. younger than Martins Pereira and Serra Dourada granites, and do not show regional deformation and metamorphic features (e.g. CPRM 2000, Almeida et al. 2002). The Caroebe granitoid rocks are coeval to volcanic rocks (Macambira et al. 2002) and both have similar geochemical characteristic (Reis et al. 2000). Locally, charnockitic (Igarapé Tamandaré) and enderbitic (Santa Maria) plutons may occur. The SUAD comprises the Igarapé Azul-Água Branca granitic terrane proposed by Almeida et al. (2002).

Several A-type granitic bodies, such as the Moderna ( 1.81 Ga, Santos et al. 1997), which is correlated to Madeira intrusive suite (CPRM 2006) with 1.82-1.79 Ga ages (e.g. Costi et al. 2000), and the Mapuera and Abonari granites $(\sim 1.87 \mathrm{Ga}$, e.g. CPRM 2003), are widespread in the UAD (Fig. 2) and cross cut the rocks described above. They are considered as related to a "post-orogenic to anorogenic" setting. All interval ages presented above have been determined mainly by single-zircon $\mathrm{Pb}$ evaporation, U-Pb ID TIMS and SHRIMP methods (Table 1).

GEOLOGY AND PETROGRAPHY RESULTS In this section will be describing the results of the mapping and the petrographical aspects of the main granitic associations of the UAD, which was subdivided into northern and southern areas. All geological and petrographical characteristics of UAD granitoid rocks are summarized in the Table 1.

\section{Northern area}

BASEMENT ROCKS: TTG-LIKE ANAUÁ COMPLEX AND CAUARANE GROUP RELATED ROCKS The Anauá Complex (CPRM 2000) crops out along Anauá and Novo rivers, and is mostly composed of $2.03 \mathrm{Ga}$ metagranitoid rocks and metadiorites, chemically comparable to calc-alkaline rocks of TTG terranes, enclosing mafic and ultramafic enclaves (Faria et al. 2003). The Anauá Complex rocks show two main deformational phases: a) $\mathrm{D}_{1}$ dominant with $\mathrm{N} 63^{\circ} \mathrm{E} / 34^{\circ} \mathrm{NW}$ foliation, and b) $\mathrm{D}_{2}$ represented by a mylonitic foliation.

The Cauarane Group rocks are associated with the Anauá Complex and represent an important metavolcano-sedimentary of low- to high-grade metamorphism, locally in anatexis. Faria et al. (2002) suggest that these supracrustal rocks are a back-arc basin sequence, related to Anauá island arc, developed in the first accretionary orogenic event of the TapajósParima cycle (Santos et al. 2000). According to CPRM (2000) this metavolcano-sedimentary sequence is correlated to the Kwitaro Group, located in south Guyana (Berrangé 1972).

The Cauarane Group comprises mica schists, quartzites, paragneisses, metacherts, phyllites and amphibolites with at least two deformational phases (CPRM 2000): a) $\mathrm{S}_{\mathrm{n}}$ main foliation (N56 $\left.{ }^{\circ} \mathrm{E} / 87^{\circ} \mathrm{SE}\right)$ and b) $\mathrm{S}_{\mathrm{n}+1}$ foliation $\left(\mathrm{N} 45^{\circ} \mathrm{E} / 70^{\circ} \mathrm{NW}\right)$. According to CPRM $(2000)$, the paragneisses are geochemically similar to immature clastic sedimentary rocks (graywackes and arkoses); the amphibolitic rocks have high $\mathrm{TiO}_{2}$ contents and MORB-REE pattern.

Detrital zircon crystals from one Cauarane schist yielded two different age populations: i) 2229 $\pm 8 \mathrm{Ma}$ (U-Pb ID-TIMS, CPRM 2003 modified from Gaudette et al. 1996) and ii) $2074 \pm 15 \mathrm{Ma}$ and 2038 $\pm 17 \mathrm{Ma}$ (U-Pb SHRIMP, CPRM 2003), this last one interpreted as the maximum age of the sedimentation. This data suggests basement sources related mainly to the Transamazonian terrains, including probably rocks from the Anauá arc.

S-TYPE SERRA DOURADA GRANITE The S-type granitoid rocks of southeastern Roraima were initially described by Faria et al. (1999). These authors have been included all granitoid rocks with S-type tipology in the Igarapé Azul granite unit. However, Almeida et al. (2002) and Almeida and Macambira (2003), based on geochemical features and more detailed geological mapping in the type area, subdivided the Igarapé Azul granite into three different granitic types: Serra Dourada granite ("truly" S-type), Martins Pereira granite (older and deformed I-type high-K calc-alkaline) and the Igarapé Azul granite (younger and undeformed Itype high-K calc-alkaline).

The S-type Serra Dourada granite has approximately $170 \mathrm{~km}^{2}$, crops out near the homonymous small town, and is intrusive in rocks from the Anauá Complex and Cauarane Group (Fig. 2). These granitoid rocks show monzogranitic and minor syenogranitic and granodioritic compositions, with diagnostic aluminous minerals, equigranular texture and coarse to medium grained (Fig 3a, Table 2). The mineral assemblage is composed of alkali feldspar (16-39\%), quartz (18-31 $\%$ ), plagioclase (19-39\%), biotite (1-21\%), muscovite (2-6\%), minor cordierite, monazite, xenotime, opaque minerals, apatite, zircon and sillimanite, and secondary minerals are epidote, titanite, chlorite and leucoxene (Table 2). Minor evidences of dynamic recrystallization and planar fabric are also present.

Quartz shows commonly embayement contacts. The slight red-brown biotite is intergrown with muscovite or occurs as subhedral isolated crystals showing several metamict mineral inclusions. Muscovite rarely occurs as large separate crystals. Cordierite appears as crystals around $2 \mathrm{~mm}$ long with sillimanite inclusions, partly to totally altered (pinitization and sericitization) and commonly having a rectangular tabular habit. Ilmenite and magnetite are also observed. Monazite and xenotime show pale yellow color to colorless and wide orange pleochroic haloes in the host mineral.

The existence of associated supracrustal rocks and aluminous paragenesis suggests that the Serra Dourada granite is derived from a metasedimentary source, involving anatexis in low (cordierite crystallization) to moderate $\mathrm{H}_{2} \mathrm{O}$-activity (minor magnetite and biotite crystallization), and low to medium pres- 


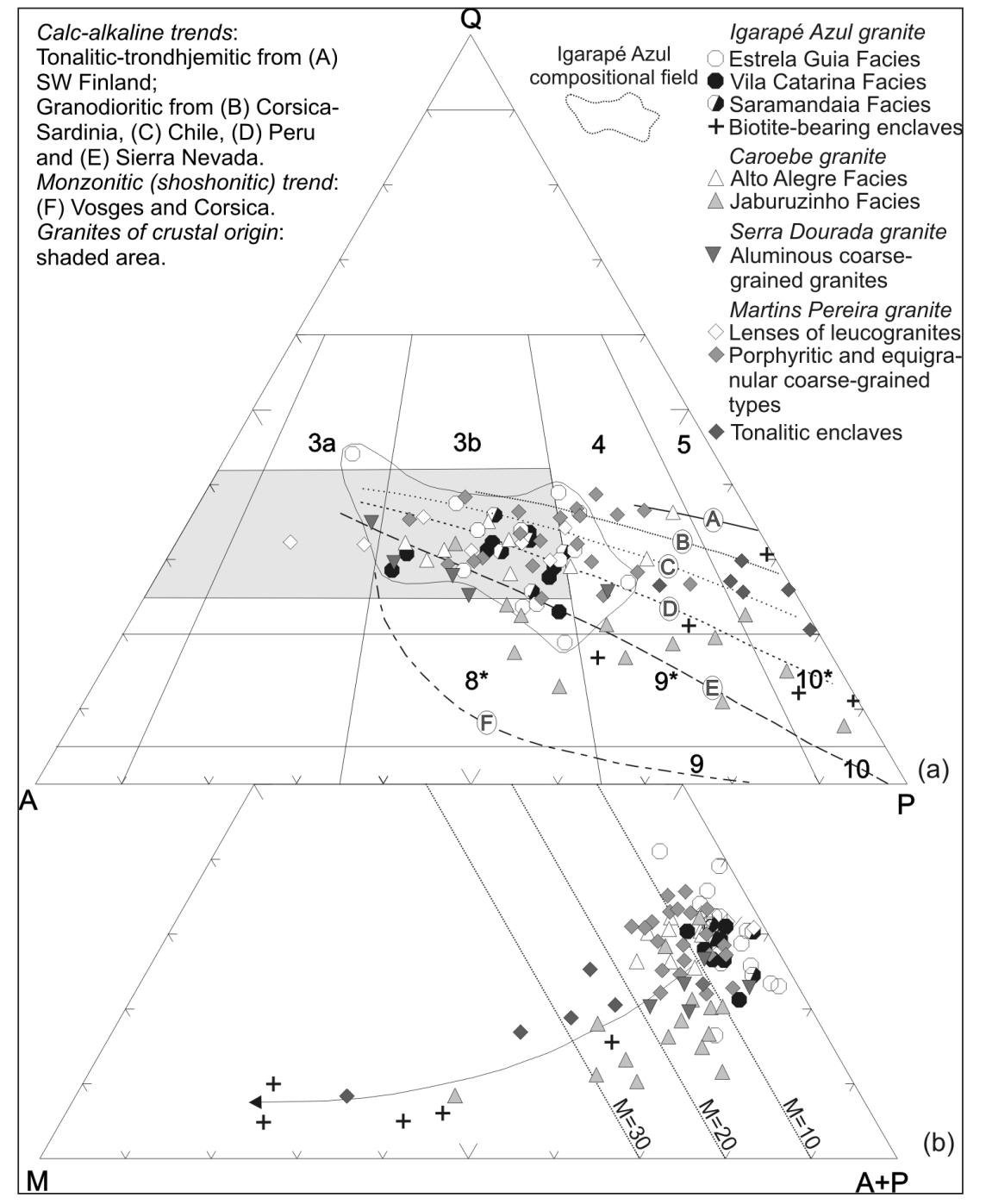

\author{
Simbols: \\ Q- Quartz; \\ A-Alkali feldspar, \\ $P$ - Plagioclase; \\ $M$ - Mafic minerals. \\ The trends of the plutonic \\ suites are from Lameyre \\ \& Bowden (1982) and \\ Lameyre and Bonin \\ (1991).
}

Fields:

3a. syenogranite;

3b. monzogranite;

4. granodiorite;

5. tonalite;

9. monzodiorite/monzogabbro; 10. diorite/gabbro;

$8^{*}$. quartz monzonite;

9*. quartz monzodioritel quartz monzogabbro;

10*. quartz diorite/quartz gabbro.

Figure 3 - QAP (a) and $Q M(A+P)$ (b) diagrams (Streckeisen, 1976) for samples from Martins Pereira, Serra Dourada, Caroebe and Igarapé Azul granitoid rocks (including enclaves). For modal contents see tables 1,2 and 3 .

sure (cordierite) conditions (White 1992). Other S-type granite was dated in Central Guiana domain by zircon U-Pb SHRIMP (CPRM 2003) that yielded ages of 1968 $\pm 3.5 \mathrm{Ma}$ (crystallization age) and 2.05 to $2.07 \mathrm{Ga}$ (lateTransamazonian inheritance).

MARTINS PEREIRA GRANITE The Martins Pereira granitoid rocks (up to $3780 \mathrm{~km}^{2}$ in area) occur southward of the Itã system fault and its main outcrops have been recorded around the Martins Pereira (type-area), Rorainópolis and São Luís do Anauá towns (Fi. 2). This batholith is composed of medium-grained porphyrytic gray granodiorites to monzogranites and locally by fine to medium-grained dark gray tonalites showing a calcalkaline granodioritic trend (Chile related; Lameyre and Bowden 1982, Lameyre and Bonin 1991) in the QAP diagram (Fig. 3a, Table 2). Small intrusive blobs and lenses of leucogranites are also associated with the batholith.

Granodiorites and monzogranites In general, the granodiorites and monzogranites are slightly blueish gray and have conspicuous porphyrytic (locally equigranular) texture with feldspar megacrysts (Fig. $4 \mathrm{a}$ and $4 \mathrm{~b}$ ), medium to coarse-grained groundmass and $10 \%$ to $18 \%$ of mafic minerals (Fig 3b, Table 2). Foliation with local banding and subparalel $\left(\mathrm{N} 75^{\circ} \mathrm{E} / 80^{\circ} \mathrm{SE}\right)$ mylonitic foliation are common in these granitoid rocks (Fig. 5a). In spite of heterogeneous solid-state deformation, only locally quartz shows in thin section high dynamic recrystallization features (Fig. 5b). Exceptionally, in ductile narrow mylonitic zones, feldspars and quartz show granoblastic texture and corel-and-mantle structure, which suggests metamorphic temperature over ca. $400^{\circ}-500^{\circ} \mathrm{C}$ (e.g. Passchier and Trouw 1996). The mineral assemblage of these rocks is composed by alkali feldspar (10-37\%), quartz (21-35\%), plagioclase (23-53\%), biotite (4-12\%), muscovite $(0.1-4 \%)$ and minor epidote, opaque minerals, titanite, allanite, apatite, zircon and rare tourmaline (Table 2).

Feldspar megacrysts (mainly alkali feldspar) have ovoid and tabular shapes (Fig. 4a), ranging in 
Table 1 - Summary of geological and petrographic characteristics of the granitoid rocks from Uatumã-Anauá domain.

\begin{tabular}{|c|c|c|c|c|c|c|}
\hline Areas & & Northern & & \multicolumn{2}{|c|}{ Southern } & \\
\hline Units & $\begin{array}{c}\text { Martins Pereira } \\
\text { granite }\end{array}$ & $\begin{array}{c}\text { Serra Dourada } \\
\text { granite }\end{array}$ & Leucogranites & \multicolumn{2}{|c|}{ Caroebe granite } & Igarapé Azul granite \\
\hline FACIES & $\begin{array}{l}\text { Normal to high } \\
\mathrm{K}+\mathrm{Th}+\mathrm{U} \text { contents }\end{array}$ & - & - & Jaburuzinho & Alto Alegre & $\begin{array}{c}\text { Vila Catarina, } \\
\text { Saramandaia, Cinco } \\
\text { Estrelas }\end{array}$ \\
\hline$A G E$ & $1.97 \mathrm{Ga}$ & $1.96 \mathrm{Ga}$ & $1.90 \mathrm{Ga}$ & $1.90 \mathrm{Ga}$ & $1.89 \mathrm{Ga}$ & $1.89 \mathrm{Ga}$ \\
\hline INHERITANCES & $2.04 \mathrm{Ga}$ & $2.14 \mathrm{Ga}$ & $\begin{array}{c}2.35 \mathrm{Ga}, 2.13 \mathrm{Ga} \\
1.96 \mathrm{Ga}\end{array}$ & - & $1.96 \mathrm{Ga}$ & $1.97-1.96 \mathrm{Ga}$ \\
\hline $\begin{array}{l}\text { Geochronological } \\
\text { methods }\end{array}$ & $\begin{array}{c}\text { Single-zircon } \mathrm{Pb} \\
\text { evaporation and } \\
\text { zircon U-Pb SHRIMP }\end{array}$ & \begin{tabular}{|} 
Single-zircon $\mathrm{Pb}$ \\
evaporation and \\
zircon U-Pb ID- \\
TIMS
\end{tabular} & $\begin{array}{l}\text { Single-zircon } \mathrm{Pb} \\
\text { evaporation }\end{array}$ & $\begin{array}{l}\text { Single-zircon } \mathrm{Pb} \\
\text { evaporation and } \\
\text { zircon U-Pb ID- } \\
\text { TIMS }\end{array}$ & $\begin{array}{c}\text { Single-zircon } \mathrm{Pb} \\
\text { evaporation }\end{array}$ & $\begin{array}{c}\text { Single-zircon } \mathrm{Pb} \\
\text { evaporation and zircon } \\
\mathrm{U}-\mathrm{Pb} \text { ID-TIMS }\end{array}$ \\
\hline Composition & $\begin{array}{l}\text { Granodiorites to } \\
\text { monzogranites, } \\
\text { locally tonalites }\end{array}$ & $\begin{array}{c}\text { Monzogranites to } \\
\text { syenogranites, rarely } \\
\text { granodiorites }\end{array}$ & $\begin{array}{c}\text { (Leuco) } \\
\text { monzogranites to } \\
\text { leucosyenogranites, } \\
\text { rarelly } \\
\text { leucogranodiorites }\end{array}$ & $\begin{array}{c}\text { Diorites to } \\
\text { monzogranites }\end{array}$ & $\begin{array}{l}\text { Granodiorite to } \\
\text { monzogranite }\end{array}$ & $\begin{array}{c}\text { (Leuco)granodiorites to } \\
\text { (leuco)monzogranites, } \\
\text { rarelly quartz monzonites } \\
\text { and syenogranites }\end{array}$ \\
\hline $\begin{array}{l}\text { Petrological } \\
\text { Trends }\end{array}$ & $\begin{array}{l}\text { Calc-alkaline } \\
\text { Granodioritic }\end{array}$ & Crustal granites & Crustal granites & \multicolumn{2}{|c|}{ Calc-alkaline Granodioritic } & Crustal granites \\
\hline Enclaves & $\begin{array}{l}\text { Metadiorites to } \\
\text { metatonalites } \\
\text { (predominate) and } \\
\text { paragneiss (scarce) }\end{array}$ & Not observed & Not observed & \multicolumn{2}{|c|}{ Mafic microgranular } & $\begin{array}{c}\text { Biotite-bearing } \\
\text { quartz diorite-tonalite } \\
\text { (surmicaceous); } \\
\text { metagranodiorite } \\
\text { (Martins Pereira); } \\
\text { paragneiss (Cauarane); } \\
\text { biotite porphyrytic } \\
\text { diorite-tonalite } \\
\text { (microgranular) }\end{array}$ \\
\hline Outcrop style & $\begin{array}{l}\text { Batholith intrusive } \\
\text { into the Anauá } \\
\text { Complex and } \\
\text { Cauarane Group }\end{array}$ & $\begin{array}{c}\text { Batholith associated } \\
\text { to metavolcano- } \\
\text { sedimentary rocks }\end{array}$ & $\begin{array}{c}\text { Blobs and lenses in } \\
\text { the Martins Pereira } \\
\text { granite }\end{array}$ & $\begin{array}{l}\text { Batholith intrusive } \\
\text { into the Martins } \\
\text { Pereira granite } \\
\text { (nucleus zone) }\end{array}$ & $\begin{array}{l}\text { Batholith intrusive } \\
\text { into the Martins } \\
\text { Pereira granite } \\
\text { (border zone) }\end{array}$ & $\begin{array}{c}\text { Batholith and small } \\
\text { bodies intrusive into the } \\
\text { Martins Pereira granite } \\
\text { and Cauarane Group }\end{array}$ \\
\hline Deformation & \begin{tabular}{|c|} 
Range in \\
deformational style \\
from well-foliated to \\
massive
\end{tabular} & $\begin{array}{l}\text { Massive to weakly } \\
\text { foliated }\end{array}$ & $\begin{array}{l}\text { Massive to weakly } \\
\text { foliated }\end{array}$ & \multicolumn{2}{|c|}{ Massive to foliated (local shear zones) } & $\begin{array}{l}\text { Massive to weakly } \\
\text { foliated (local shear } \\
\text { zones) }\end{array}$ \\
\hline Varietal minerals & $\begin{array}{l}\text { Biotite, local } \\
\text { muscovite }\end{array}$ & Biotite, muscovite & Biotite, muscovite & $\begin{array}{l}\text { Hornblende, } \\
\text { biotite and local } \\
\text { clinopyroxene }\end{array}$ & $\begin{array}{l}\text { Biotite, rare } \\
\text { hornblende }\end{array}$ & Biotite, muscovite \\
\hline $\begin{array}{l}\text { Main accessory } \\
\text { minerals }\end{array}$ & $\begin{array}{c}\text { Epidote, allanite, } \\
\text { apatite }\end{array}$ & $\begin{array}{c}\text { Cordierite, } \\
\text { sillimanite, monazite } \\
\text { and xenotime }\end{array}$ & $\begin{array}{c}\text { Epidote, titanite, } \\
\text { allanite, local garnet }\end{array}$ & $\begin{array}{c}\text { Titanite, epidote, } \\
\text { allanite, Fe-Ti oxides }\end{array}$ & $\begin{array}{c}\text { Titanite, epidote, } \\
\text { allanite }\end{array}$ & Epidote \\
\hline $\begin{array}{l}\text { Main secondary } \\
\text { minerals }\end{array}$ & $\begin{array}{c}\text { Chlorite, saussurite, } \\
\text { minor prehnite and } \\
\text { leucoxene }\end{array}$ & $\begin{array}{l}\text { Chlorite, saussurite, } \\
\text { epidote, titanite, } \\
\text { minor leucoxene }\end{array}$ & $\begin{array}{l}\text { Chlorite, saussurite, } \\
\text { minor carbonate }\end{array}$ & $\begin{array}{l}\text { Chlorite, epidote, } \\
\text { saussurite, titanite, } \\
\text { muscovite }\end{array}$ & $\begin{array}{l}\text { Chlorite, epidote, } \\
\text { saussurite, } \\
\text { muscovite, minor } \\
\text { prehnite }\end{array}$ & $\begin{array}{c}\text { Epidote, chlorite, } \\
\text { saussurite, leucoxene, } \\
\text { minor titanite }\end{array}$ \\
\hline
\end{tabular}

size from 2 to $8 \mathrm{~cm}$ and presenting white to slightly pink colors. They are enclosed by weakly to highly deformed and foliated groundmass. These megacrysts are parallel to the foliation, including also types in which the groundmass does not have strong anisotropic fabric (magma flow?). Plagioclase is weakly zoned and locally shows obliterated multiple twining. Highly altered calcic cores are uncommon. Anhedral to subhedral quartz shows ondulatory extinction or partially recrystalized grains. Drop-like quartz inclusions are common in the alkali feldspar megacrysts. Subhedral biotite has brown-greenish to straw-yellow colors, medium grain size and is associated with epidote, opaque minerals, allanite, titanite and rarely with tourmaline prysmatic crystals. Biotite crystals are frequently oriented, over- coat in highly deformed types. In this case, the biotite cleavages are filled with iron-titanium oxides, locally wick and folded kink forming bands. Biotite also occurs partially replaced by muscovite and chlorite. Muscovite occurs as irregular grains, mostly associated with biotite. Prismatic or irregular muscovite crystals also replace plagioclase and alkali feldspar megacrysts.

Blobs and lenses of leucogranites Leucogranites show granodioritic to syenogranitic compositions, equigranular and medium to coarse grained texture. They are very restricted and crops out as blobs, veins and lenses with few centimeters (rarely 5 meters) thick, subconcordant to the foliation of Martins Pereira host rock. The contacts between leucogranites and foliated 
Table 1 (Cont.)- Summary of geological and petrographic characteristics of the granitoid rocks from UatumãAnauá domain.

\begin{tabular}{|c|c|c|c|c|c|c|}
\hline Areas & & Northern & & \multicolumn{2}{|c|}{ Southern } & \\
\hline Units & $\begin{array}{l}\text { Martins Pereira } \\
\text { granite }\end{array}$ & $\begin{array}{l}\text { Serra Dourada } \\
\text { granite }\end{array}$ & Leucogranites & \multicolumn{2}{|c|}{ Caroebe granite } & Igarapé Azul granite \\
\hline Quartz & $\begin{array}{c}\text { Anhedral to } \\
\text { subhedral, ondulatory } \\
\text { extinction, partially } \\
\text { recrystallized. }\end{array}$ & $\begin{array}{c}\text { Anhedral } \\
\text { (embayement), } \\
\text { medium to fine } \\
\text { grained, partially } \\
\text { recrystallized grains }\end{array}$ & $\begin{array}{l}\text { Subhedral to } \\
\text { anhedral, fine } \\
\text { to medium- } \\
\text { grained. Partial } \\
\text { recrystallization }\end{array}$ & \begin{tabular}{|} 
Anhedral and \\
medium grained to \\
subhedral and fine \\
to medium grained, \\
ondulatory extinction \\
and variable \\
recrystallization \\
stages
\end{tabular} & \begin{tabular}{|c|} 
Heterogranular, \\
anhedral, local \\
monocrystalline \\
aggregates. \\
Ondulatory extinction \\
and variable \\
recrystallization \\
stages
\end{tabular} & $\begin{array}{l}\text { Fine to coarse-grained, } \\
\text { anhedral, sometimes } \\
\text { interstitial. Locally } \\
\text { fractured with ondulatory } \\
\text { extinction. Partially } \\
\text { recrystallized }\end{array}$ \\
\hline Plagioclase & $\begin{array}{l}\text { Subhedral crystal } \\
\text { weakly zoned and } \\
\text { local obliterated } \\
\text { multiple twining. }\end{array}$ & $\begin{array}{c}\text { Subhedral } \\
\text { and corroded } \\
\text { crystals with no } \\
\text { compositional zoning } \\
\text { and local grains with } \\
\text { no twining }\end{array}$ & \begin{tabular}{|} 
Subhedral to \\
anhedral, slight \\
compositional \\
zoning. Ondulatory \\
extinction
\end{tabular} & $\begin{array}{l}\text { Subhedral to } \\
\text { euhedral, tabular, } \\
\text { medium to coarse } \\
\text { grained, oscillatory } \\
\text { compositional } \\
\text { zoning. }\end{array}$ & \begin{tabular}{|c|} 
Subhedral to \\
euhedral, local \\
embayement \\
contacts, medium \\
to coarse grained. \\
Normal to oscillatory \\
compositional zoning
\end{tabular} & $\begin{array}{c}\text { Euhedral, local } \\
\text { oscillatory zoning, } \\
\text { oriented by magma } \\
\text { flow (megacrysts). } \\
\text { Subhedral to anhedral, } \\
\text { tabular, medium to fine- } \\
\text { grained, normal zoning } \\
\text { (groundmass) }\end{array}$ \\
\hline Alkali feldspar & \begin{tabular}{|} 
Subhedral tabular and \\
ovoid, coarse grained, \\
white to slightly \\
pink, Tartan twinning \\
(megacrysts). \\
Subhedral \\
to anhedral, \\
medium-grained \\
(groundmass). \\
Ondulatory \\
extinction.
\end{tabular} & $\begin{array}{l}\text { Anhedral coarse- } \\
\text { grained, Tartan } \\
\text { twinning }\end{array}$ & \begin{tabular}{|} 
Subhedral to \\
anhedral, tabular, \\
medium to coarse \\
grained, Tartan \\
twinning. Local \\
microperthites and \\
ondulatory extinction.
\end{tabular} & $\begin{array}{l}\text { Anhedral, tabular, } \\
\text { microperthite, } \\
\text { Tartan and/or } \\
\text { Carlsbad twinning, } \\
\text { (megacryst), } \\
\text { subhedral, } \\
\text { weak twinning } \\
\text { (groundmass). } \\
\text { Ondulatory } \\
\text { extinction. Local } \\
\text { recrystallization }\end{array}$ & \begin{tabular}{|} 
Medium to coarse \\
grained, anhedral, \\
perthitic and poikilitic \\
(megacryst), fine \\
grained, euhedral \\
to subhedral, \\
Tartan twinning \\
(groundmass). Local \\
recrystallization
\end{tabular} & $\begin{array}{l}\text { Anhedral, microperthitic, } \\
\text { myrmekite intergrowth } \\
\text { (megacrysts). Partially } \\
\text { altered to sericite and } \\
\text { muscovite. Subhedral } \\
\text { to anhedral, fine to } \\
\text { medium grained, Tartan } \\
\text { (and Carlsbad) twinning } \\
\text { (groundmass) }\end{array}$ \\
\hline Biotite & $\begin{array}{l}\text { Brown-greenish } \\
\text { to straw-yellow, } \\
\text { subhedral, medium } \\
\text { grained. Oriented, } \\
\text { locally wick and } \\
\text { folded kink } \\
\end{array}$ & $\begin{array}{l}\text { Light red-brown, } \\
\text { subhedral. Metamict } \\
\text { mineral inclusions } \\
\text { Intergrown with } \\
\text { muscovite. }\end{array}$ & $\begin{array}{c}\text { Straw yellow, slightly } \\
\text { ondulatory extinction, } \\
\text { medium to fine- } \\
\text { grained }\end{array}$ & $\begin{array}{c}\text { Straw yellow to } \\
\text { greenish yellow, } \\
\text { subhedral to euhedral. } \\
\text { Oriented by magma } \\
\text { or locally solid-state } \\
\text { flow }\end{array}$ & \begin{tabular}{|} 
Straw yellow to \\
yellow greenish, \\
subhedral, medium \\
grained. Oriented by \\
magma or solid-state \\
flow
\end{tabular} & $\begin{array}{l}\text { Straw yellow to brown } \\
\text { greenish (or rarely red } \\
\text { brownish) subhedral, } \\
\text { fine to coarse grained. } \\
\text { Slightly oriented }\end{array}$ \\
\hline Muscovite & \begin{tabular}{|c|} 
Irregular grains \\
mostly associated \\
with biotite. Prismatic \\
or irregular crystals \\
replace plagioclase \\
and alkali feldspar
\end{tabular} & $\begin{array}{l}\text { Intergrown with } \\
\text { biotite, locally } \\
\text { as large separate } \\
\text { (primary?) crystals }\end{array}$ & $\begin{array}{c}\text { Ondulatory } \\
\text { extinction. Replaces } \\
\text { biotite and } \\
\text { plagioclase }\end{array}$ & $\begin{array}{c}\text { Uncommon and } \\
\text { partially replaces } \\
\text { biotite }\end{array}$ & $\begin{array}{l}\text { Uncommon and } \\
\text { partially replaces } \\
\text { biotite }\end{array}$ & Partially replaces biotite \\
\hline Hornblende & - & - & - & \begin{tabular}{|c|} 
Subhedral to \\
euhedral, straw \\
yellow, dark olive \\
green to dark green. \\
Rare clinopyroxene \\
preserved in the cores
\end{tabular} & - & - \\
\hline
\end{tabular}

granitoid rock hosts are lobate to irregular, occasionally diffuse, and progressively change to regular and concordant style (Fig. 6). These leucogranites are more commom near to the Igarapé Azul contacts.

The rocks are characterized by a grayish white color, generally with sugar-like and isotropic fabric, locally showing dynamic recrystallization and cataclastic features. The mineral assemblage is composed by alkali feldspar (21-55\%), quartz (27-33\%), plagioclase (8-42 $\%)$, biotite (1-5\%), muscovite $(0.1-3 \%)$, and minor epidote, opaque minerals, titanite, allanite, apatite and zircon (Table 2).

Alkali feldspar is medium to coarse grained, subhedral to anhedral, and tabular, showing locally microperthites and ondulatory extinction. It encloses pla- gioclase, quartz and muscovite. Sericitization and fractures are also present. Plagioclase shows slight compositional zoning, locally marked by cores with secondary alteration (epidote, carbonate and sericite). It is tabular, subhedral, locally embayed with alkali feldspar grains and shows slight ondulatory extinction. Quartz has ondulatory extinction, is partially recrystallized, subhedral to anhedral and fine to medium-grained with abundant embayement features. Biotite has moderate pleocroism, straw yellow color, slightly ondulatory extinction, medium to fine-grain size. It is partially to totally transformed into muscovite. Muscovite occasionally occurs as isolated crystals with ondulatory extinction and associated with biotite and plagioclase. Tourmaline and igneous garnet are uncommon. 


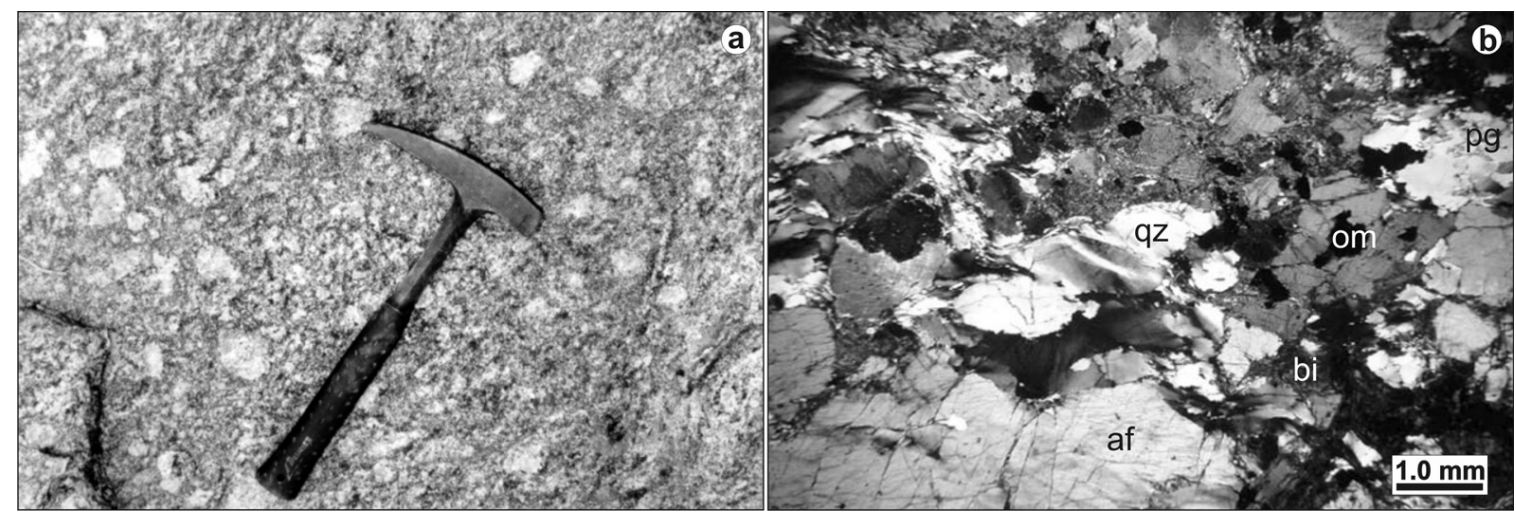

Figure 4 - Features of the Martins Pereira granitoid rocks: a) Isotropic porphyrytic biotite monzogranite (outcrop MA-218), showing ovoid alkali feldspar megacrysts (<80 mm in diameter). b) Photomicrography of slightly oriented biotite, dynamically recrystallized quartz and fractured alkali feldspar (cross-polarized light, 1.25x). Obs: af. alkali feldspar, pg. plagioclase, qz. quartz, biotite, om. opaque mineral.

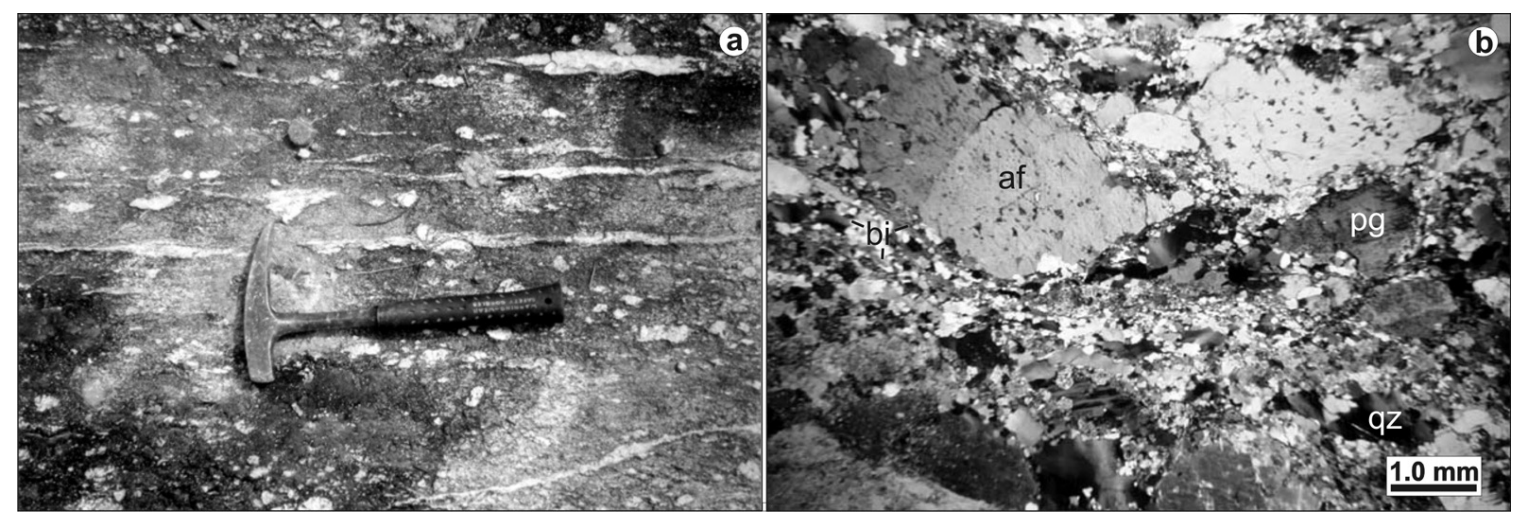

Figure 5 - Deformational features of the Martins Pereira granitoid rocks: a) Biotite monzogranite (porphyrytic facies) showing mylonitic foliation $\left(N 75^{\circ} \mathrm{E} / 90^{\circ}\right.$ to $\left.N 82^{\circ} \mathrm{E} / 90^{\circ}\right)$, rounded megacrysts with pressure shadows and locally quartz ribbons in dextral shear zone (outcrop MA-61). b) Photomicrography showing protomylonitic texture. Note the local groundmass grain reduction by dynamic recrystallization, oriented mafic minerals and rounded alkali feldspar megacrysts (crosspolarized light, 1.25x). Obs: af. alkali feldspar, pg. plagioclase, qz. quartz, bi. biotite.

Enclaves Tonalitic (and minor granodioritic) rocks in the Martins Pereira granitoid rocks may occur as oblate and ellipsoidal enclaves concordant with the foliation of the host rock (Fig. 7a). Furthermore, these enclaves have an internal structure visible at naked eye, emphasized by biotite crystals, systematically parallel to the foliation of the host rock. These elongate biotitebearing tonalitic enclaves, and the leucogranitic blobs and lenses are concordant to subconcordant to the structures of the host rocks, generating local banding.

The tonalitic enclaves are foliated and characterized by equigranular, medium to fine grained (Fig. 7b) with local slightly ondulatory extinction in quartz and feldspar crystals, although recrystallization and mineral stretching is not observed. They show high mafic mineral contents (Fig. 3b, Table 2), such as epidote (0.1-13\%), titanite (1-4\%) and biotite (3-42 $\%)$, the last one partially replaced by muscovite (1-6\%) and chlorite (0.1-14\%). Other accessory minerals are allanite, apatite, magnetite and zircon.

Other enclaves observed as xenoliths of amphibolites, hornblende-rich metaigneous rocks of the Anauá Complex and paragneisses of the Cauarane Group, but they are rare. Amphibolitic and metaigneous enclaves with dioritic to quartz-monzodioritic compositions are quite angular with slightly rounded vertices, greenish and isotropic to foliated. They are locally disrupted by tonalitic veins network, but both (amphibolitic and tonalitic types) are enclosed by Martins Pereira granitoid rocks. These xenoliths are equigranular, medium to coarse grained and have high mafic contents $(45 \%)$. Plagioclase $(40 \%)$ and quartz $(10 \%)$ show ondulatory extinction and local dynamic recrystallization features. The accessory minerals are mainly opaque minerals (3\%), epidote $(1 \%)$ and apatite. Paragneissic xenoliths with $\mathrm{cm}$-scale, angular shape and fine to medium-grained are very rare. They have an internal structure marked by micaceous bands 


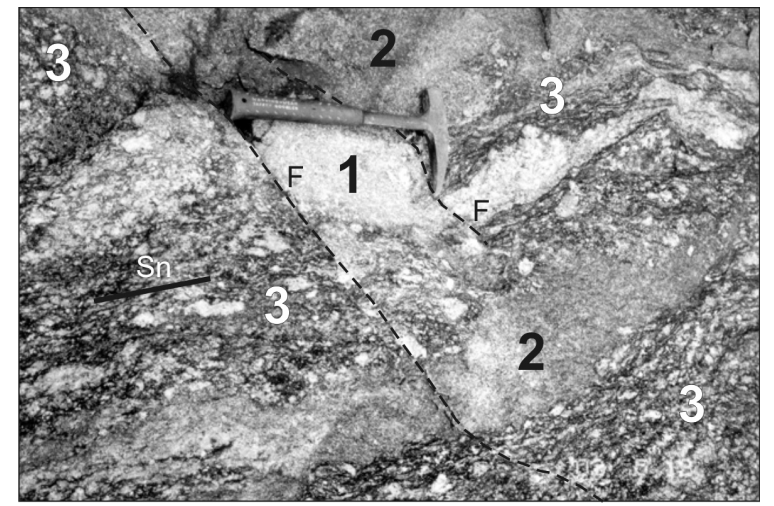

Figure 6 - Outcrop (MA-07) of the Martins Pereira granitoid rocks showing blobs and lenses of leucogranite (1) and monzogranite (2) in porphyrytic biotite granodiorite (3) with $N 80^{\circ} \mathrm{W} / 18^{\circ} \mathrm{NE}$ strike foliation locally disrupted by NS normal faults $(F)$.

and metasedimentary relicts.

\section{Southern area}

CAROEBE GRANITE Calc-alkaline granitic bodies in southern Roraima (Costi et al. 1984, Oliveira et al. 1996, CPRM 2000, Almeida et al. 2002) has been associated to the Água Branca suite (Araújo Neto and Moreira 1976, Veiga et al. 1979, Jorge-João et al. 1985). The main granitic body of Água Branca suite in this region, named as Caroebe granite, is located south of Rorainópolis, São Luiz do Anauá, São João da Baliza and Caroebe towns in the region of the Jauaperi and Anauá river basins.

The Caroebe granite has about $65000 \mathrm{~km}^{2}$ (CPRM 2003) and extends to northwestern Pará and northeastern Amazonas states. Only the northwestern part (near to $4000 \mathrm{~km}^{2}$ ) of this pluton has been studied up to now. This granitic batholith was emplaced along EW to ENE-WNW structures, parallel to Martins Pereira (meta)granitoid rocks regional foliation, which is observed in other minor and similar granitic bodies of the region (Fig. 2). Neogene sediments recover the western side of the Caroebe granite. In the eastern and north sides it is in contact with coeval volcanic rocks (Reis and Fraga 1996; Reis et al. 2000, Macambira et al. 2002) and is intrusive into Martins Pereira (meta) granitoid rocks.

The Caroebe granite is characterized by extended compositional granitic association and calcalkaline granodioritic series such as the Peru and Sierra Nevada trends (Lameyre and Bowden 1982, Lameyre and Bonin 1991, Fig. 3a). They are subdivided into two main petrographic facies: Alto Alegre and Jaburuzinho (Fig. 2).

Jaburuzinho facies The Jaburuzinho facies consists of hornblende-bearing granitoid rocks, such as granodiorites, monzogranites and tonalites, with minor diorites, quartz monzodiorites and quartz diorites (Fig. 3a, Table 3). The main outcrops are located in Anauá (Jaburuzinho creek) and Jauaperi river basins. They show homogeneous, equigranular to porphyrytic textures (10\% to $15 \%$ megacrysts), are medium to coarse grained and show gray color. The tabular alkali feldspar megacrysts show white to slightly pinkish color, and 15 to $25 \mathrm{~mm}$ in length, locally up to $50 \mathrm{~mm}$ (ratio $1: 3$ ), and ENE-WSW orientation, suggesting magma flow process.

These granitoid rocks have also abundant mafic clots and rounded circular autholiths (Fig. 8a), including variable mafic mineral contents (12\%-65\%, Fig. $3 \mathrm{~b})$. The mafic clots are sometimes interlinked and slightly oriented, without solid-state deformation evidence, which points out also to magma flow structure. On the other hand, granitoid rocks submitted to solid-state deformation are very rare, related with a strong ENEWSW shear zone (Jauaperi fault system), that affects the Jauaperi and Branquinho rivers. The mineral assemblage (Table 3 ) is formed by plagioclase (23-54\%), quartz (4-30\%), alkali feldspar (2-35\%), biotite (6-20 $\%)$, hornblende $(0.3-37 \%)$, opaque minerals (mainly

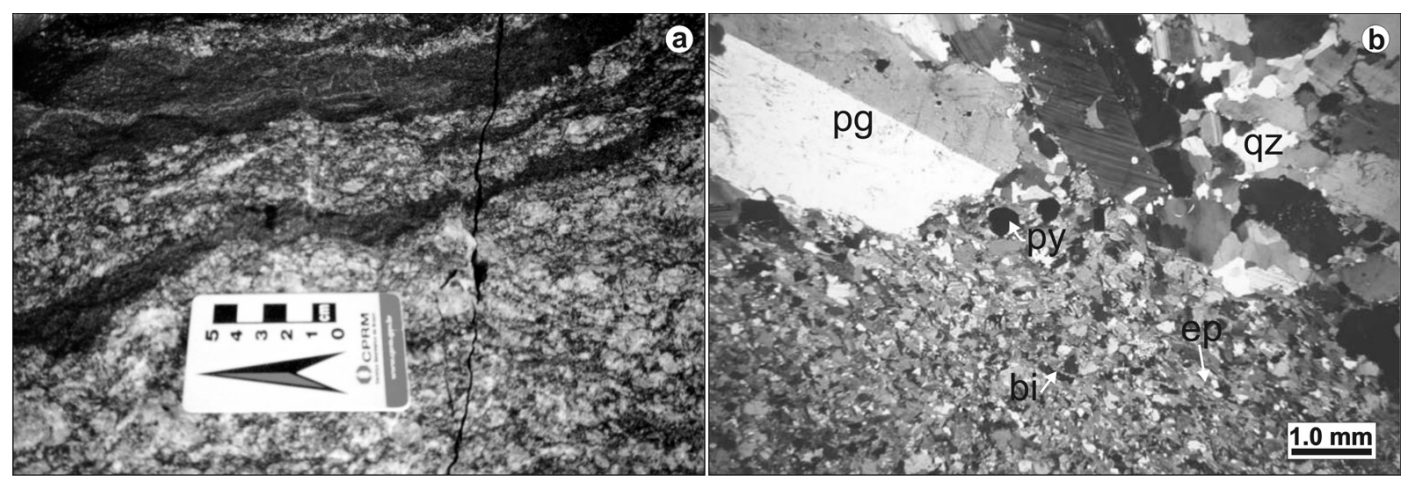

Figure 7 - Features of the Martins Pereira granitoid rocks: a) Deformed biotite granodiorite (porphyrytic facies) showing lenses of mafic tonalitic gneiss (outcrop MA-07). b) Photomicrography showing porphyrytic granodiorite host (uppermost) and biotite-bearing tonalite enclave (lowermost) contact (cross-polarized light, 1.25x).

Obs: pg. plagioclase, qz. quartz, bi. biotite, ep. epidote, py. pyrite. 
Table 2 - Modal mineral contents of samples from Martins Pereira and Serra Dourada granitoid rocks and associated rocks. Modal analysis from (1) Sardinha (1999), (2) CPRM (2000) and (3) this paper. Serra Dourada Granite: A. aluminous coarse-grained granites. Martins Pereira granitoid rocks: B. porphyrytic and equigranular coarse grained, C. blobs and lenses, D. biotite-bearing enclaves. Abbreviations: qz. quartz, af. alkali feldspar, pg. plagioclase, bi. biotite, ms. muscovite, tt. titanite, al. allanite, ep. epidote, zi. zircon, ap. apatite, om. opaque minerals, $c d$. cordierite, gr. garnet, si. sillimanite, tu. tourmaline, $m z-x t$. monazite and/or xenotime, cl. chlorite, lx. leucoxene, ss. saussurite, cb. carbonate, ph. prehnite, tr. trace, ref. references.

\begin{tabular}{|c|c|c|c|c|c|c|c|c|c|c|c|c|c|c|c|c|c|c|c|c|c|c|c|c|c|}
\hline amples & assi & facies & qz & af & $\mathrm{pg}$ & bi & $\mathrm{ms}$ & $\mathrm{tt}$ & al & ep & zi & ap & om & cd & gr & si & tu & $\begin{array}{c}\mathrm{mz}- \\
\mathrm{xt} \\
\end{array}$ & $\mathrm{cl}$ & lx & ss & my & ph & $\mathrm{cb}$ & ref. \\
\hline-151 & nogranite & A & \begin{tabular}{|l|l}
31.0 \\
\end{tabular} & \begin{tabular}{|l|l}
39.0 \\
\end{tabular} & \begin{tabular}{|l|}
19.0 \\
\end{tabular} & 5.0 & 0 & - & - & $\operatorname{tr}$ & tr & $\operatorname{tr}$ & 1.0 & 2.0 & & $\operatorname{tr}$ & - & $\operatorname{tr}$ & $\operatorname{tr}$ & - & II & - & - & & 2 \\
\hline-156 & ite & & .0 & 5.5 & 0.6 & 8 & .0 & - & . & - & \begin{tabular}{|l|}
0.2 \\
\end{tabular} & t & 8 & 2.8 & & 0.4 & - & 0.5 & 0.2 & 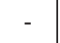 & 1.2 & 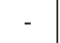 & - & & 3 \\
\hline-157 & & & 1.0 & 9.0 & 7.0 & 3.0 & 5.0 & & & $\mathrm{t}$ & 1.0 & .0 & 0 & .0 & & & & & & tr & $\operatorname{tr}$ & - & & & 2 \\
\hline & & & & & & & & & & & 0.3 & & & & & & & & & & .1 & 0.7 & & & 3 \\
\hline & & & & & 8 & & & 12 & & 2.0 & & & & & & & & & & & & & & & 3 \\
\hline & & & & & & & & & & & & & & & & & & & & & & & & & \\
\hline $\mathrm{L}-0$ & & & & 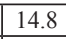 & & & & & & & & & & & & & & - & & & & & & & $\pi$ \\
\hline & & & \begin{tabular}{|l|l}
34.5 \\
\end{tabular} & 28.4 & .1 & 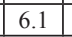 & & & $\overline{01}$ & 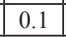 & 0.1 & & & & & & & - & & & & & & & 1 \\
\hline-05 & & B & \begin{tabular}{|l|}
32.8 \\
\end{tabular} & 10.6 & 46.3 & 7.2 & 1.0 & 0.3 & - & 0.4 & 0 & 2 & 07 & - & - & - & - & - & 0.1 & - & 3 & - & - & - & 1 \\
\hline $\mathrm{J}-024 \mathrm{~B} 2$ & & B & 3 & 36.6 & 23.3 & .3 & \begin{tabular}{|l|l|} 
& \\
\end{tabular} & .1 & - & - & \begin{tabular}{|l|l|} 
& 0.1
\end{tabular} & 0 & $\mid 0.8$ & - & - & - & - & - & 0.1 & 0.2 & 0.3 & - & - & - & 1 \\
\hline & & & & 20.0 & 3.6 & & 1.1 & & & 0.9 & & & & & & & & - & & & & & & & 1 \\
\hline & $\mathrm{m}$ & & 3 & 17.1 & 38.3 & & 2.2 & & - & & & & & & & & & & & 0.1 & & & & & 1 \\
\hline A-007A & & B & 31.4 & 22.8 & 32.2 & 9.7 & 0.8 & 0.5 & 0.2 & \begin{tabular}{|l|l|} 
& 0.7
\end{tabular} & 0.1 & \begin{tabular}{|l|} 
\\
\end{tabular} & 1.3 & - & - & - & - & - & & - & - & - & - & - & 3 \\
\hline I-213A & & B & 31.0 & 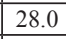 & 80 & 5.0 & 2.0 & 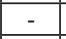 & 1.0 & \begin{tabular}{|l|l|} 
& 0.1 \\
\end{tabular} & 1.0 & 10 & 10 & & & & & 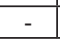 & & & 0.5 & & & & 2 \\
\hline & & & .0 & 28.0 & 29.0 & 5.0 & $\begin{array}{l}2.0 \\
\end{array}$ & \begin{tabular}{|l|l|} 
\\
\end{tabular} & & 0.1 & 1.0 & 1.00 & 1.0 & - & - & - & - & - & .4 & 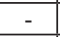 & . & - & - & - & 2 \\
\hline A- 045 & & B & 30.2 & $\mid 13.1$ & 35.9 & 1.4 & \begin{tabular}{|l|l|} 
& 1.0
\end{tabular} & 1.0 & 1.0 & \begin{tabular}{|l|l|}
1.7 \\
\end{tabular} & 0.0 & 1.0 & 1.7 & - & - & - & - & - & 0.0 & - & 0.7 & 0.3 & 1.0 & - & 3 \\
\hline & & & & 10.4 & .7 & 6.0 & 2.1 & & 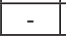 & & & & & & & 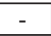 & 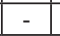 & 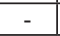 & & - & & 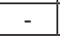 & 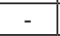 & - & 1 \\
\hline $\mathrm{J}-055 \mathrm{~A}$ & & B & 29.7 & 23.7 & 38.2 & 5.5 & 1.2 & 0.2 & - & 0.5 & 0.1 & 0.1 & 0.6 & - & - & - & - & - & 0.1 & - & 0.1 & - & - & - & 1 \\
\hline & & & & & & & & & & & & & & & & & & & & & & & & & \\
\hline & & & & & & & & & & & & & & & & & & & & & & & & & 1 \\
\hline $2 \mathrm{~A}$ & & B & 28.0 & .0 & 6.0 & 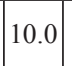 & 5 & 1.0 & - & 0.3 & 0 & 1.0 & 1.0 & - & - & - & - & - & 0.5 & - & 1.0 & - & - & - & 2 \\
\hline & & I & & & & & & & & & & & & & & & & . & & & & & & - & 1 \\
\hline & & & & & & & & & - & & & & & & & & & & 0 & & & & & & 2 \\
\hline & & & & & & & & & & & 0 & & & & & & & & & & 7.1 & \begin{tabular}{|l|}
1.1 \\
\end{tabular} & 0.4 & & 3 \\
\hline & & $\mathrm{H}$ & 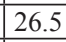 & 2 & 3.0 & & & & & & & 1 & & & & & & & & & 0. & & & & 2 \\
\hline & & B & 1 & 8 & 43.2 & 5.0 & 4.4 & 0.1 & 0.1 & 1.2 & $\mid 0.1$ & 0 & 0.7 & - & - & - & - & - & 0. & 0.1 & - & - & - & - & 1 \\
\hline & & & & & & & & & & & & & & & & & & & & & & & & & 3 \\
\hline & & B & & & & & & - & - & & - & & & & - & & - & - & & . & \begin{tabular}{|l|l|}
0.1 \\
\end{tabular} & & & - & 2 \\
\hline & granod & L & 24.7 & 14.6 & .1 & 7.8 & 0.1 & ( & 0.1 & 3.3 & 0.1 & 0.1 & 0.1 & - & 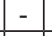 & 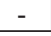 & - & - & 0.1 & - & - & 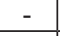 & 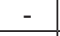 & - & 1 \\
\hline-119 & Inonz & B & 24.1 & 27.6 & 23.9 & 12.1 & - & 2.0 & - & 2.9 & 0.3 & $\operatorname{tr}$ & 0.3 & - & - & - & - & - & 0.5 & & 4.6 & 1.1 & - & - & 3 \\
\hline NI- 010 & & B & 22.7 & 2 & 41.9 & 3 & 0.2 & 0.3 & 0.1 & 0.4 & 0.1 & 0.2 & 0 & - & - & - & - & - & - & - & 0 & - & - & - & 1 \\
\hline 159 & nod & 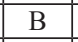 & 22.6 & 9. & 52.5 & 10.7 & - & 2.3 & - & 0. & 0. & 0 & 0. & - & - & - & - & - & 0.1 & - & \begin{tabular}{|l|}
0.4 \\
\end{tabular} & - & - & - & 1 \\
\hline DB & & B & 20.5 & 3.4 & 0.2 & 9.2 & - & 6 & - & 1.1 & 0.2 & 0.4 & 1.1 & - & & ${ }^{-}$ & 0.7 & - & - & - & 0.4 & 1.1 & - & - & 3 \\
\hline
\end{tabular}

\begin{tabular}{l|l|c|c|c|c|c|c|c|c|c|c|c|c|c|c|c|c|c|c|c|c|c|c|c|c}
\hline MJ-013C & $\begin{array}{l}\text { leucograno- } \\
\text { diorite }\end{array}$ & $\mathrm{C}$ & 32.5 & 21.1 & 41.7 & 3.0 & 0.3 & 0.1 & 0.1 & 0.7 & 0.1 & 0.1 & 0.2 & - & - & - & - & - & 0.1 & - & - & - & - & - & 1 \\
\hline MF-011C2 $\begin{array}{l}\text { leucomonzo- } \\
\text { granite }\end{array}$ & $\mathrm{C}$ & 31.4 & 27.4 & 38.7 & 1.2 & 0.1 & 0.1 & - & 0.3 & 0.1 & 0.1 & 0.1 & - & - & - & - & - & 0.2 & - & 0.3 & - & - & - & 1 \\
\hline MA-246C2 2 & $\begin{array}{l}\text { leucosyeno- } \\
\text { granite }\end{array}$ & $\mathrm{C}$ & 30.8 & 54.6 & 8.4 & $\mathrm{tr}$ & 0.3 & - & - & 1.0 & 0.1 & $\mathrm{tr}$ & $\mathrm{tr}$ & - & - & - & - & - & - & - & 4.4 & - & - & 0.5 & 3 \\
\hline MA-46B & monzogranite & $\mathrm{C}$ & 30.2 & 34.3 & 20.9 & 4.9 & 3.2 & - & - & 0.2 & $\mathrm{tr}$ & $\mathrm{tr}$ & 1.4 & - & $\mathrm{tr}$ & - & - & - & 0.2 & - & 4.3 & 0.4 & - & - & 3 \\
\hline RL-138 & $\begin{array}{l}\text { leucomonzo- } \\
\text { granite }\end{array}$ & $\mathrm{C}$ & 30.2 & 33.4 & 33.3 & 1.3 & 0.1 & 0.1 & 0.1 & 0.8 & 0.1 & 0.1 & 0.5 & - & - & - & - & - & - & - & - & - & - & - & 1 \\
\hline MA-007B & $\begin{array}{l}\text { leucosyeno- } \\
\text { granite }\end{array}$ & $\mathrm{C}$ & 29.8 & 43.1 & 20.1 & 1.9 & 2.8 & 0.2 & 0.6 & 0.6 & 0.1 & 0.1 & 0.6 & - & - & - & - & - & 0.1 & - & - & - & - & - & 3 \\
\hline MF-012 & monzogranite & $\mathrm{C}$ & 27.1 & 23.5 & 40.1 & 4.4 & 1.8 & 0.4 & - & 1.4 & 0.1 & 0.2 & 0.6 & - & - & - & - & - & 0.1 & - & 0.3 & - & - & - & 1 \\
\hline
\end{tabular}

\begin{tabular}{l|l|c|c|c|c|c|c|c|c|c|c|c|c|c|c|c|c|c|c|c|c|c|c|c|c}
\hline MA-246C1 & tonalite gneiss & $\mathrm{D}$ & 21.6 & 2.7 & 26.4 & 3.4 & 5.8 & 3.8 & 0.3 & 5.5 & 0.3 & 0.3 & 1.7 & - & - & - & - & - & 14.0 & - & 13.7 & - & - & 0.3 & 3 \\
\hline MA-176B & $\begin{array}{l}\text { metagrano- } \\
\text { diorite }\end{array}$ & $\mathrm{D}$ & 20.5 & 15.1 & 42.8 & 8.8 & 1.6 & tr & tr & 3.1 & 0.3 & tr & 0.5 & - & - & - & - & - & 0.3 & & 5.4 & 1.6 & - & - & 3 \\
\hline MF-073B2 & tonalite & $\mathrm{D}$ & 20.0 & 5.0 & 50.0 & 15.0 & 1.0 & 1.0 & - & 2.0 & - & 2.0 & 3.0 & - & - & - & - & - & 1.0 & - & - & - & - & - & 2 \\
\hline RL-040B & tonalite gneiss & $\mathrm{D}$ & 18.0 & 4.0 & 48.0 & 20.0 & 1.0 & - & - & 2.0 & - & 2.0 & 3.0 & - & - & - & - & - & 1.0 & - & 1.0 & - & - & - & 2 \\
\hline MA-009B & tonalite gneiss & $\mathrm{D}$ & 17.0 & - & 48.0 & 29.9 & - & 1.0 & - & 0.1 & 0.1 & 0.5 & 3.4 & - & - & - & - & - & - & - & - & - & - & - & 3 \\
\hline MA-007C & tonalite gneiss & $\mathrm{D}$ & 8.5 & - & 32.1 & 42.4 & - & 2.2 & 0.8 & 12.5 & 0.2 & 0.4 & 0.8 & - & - & - & tr & - & 0.1 & - & - & - & - & & 3 \\
\hline
\end{tabular}




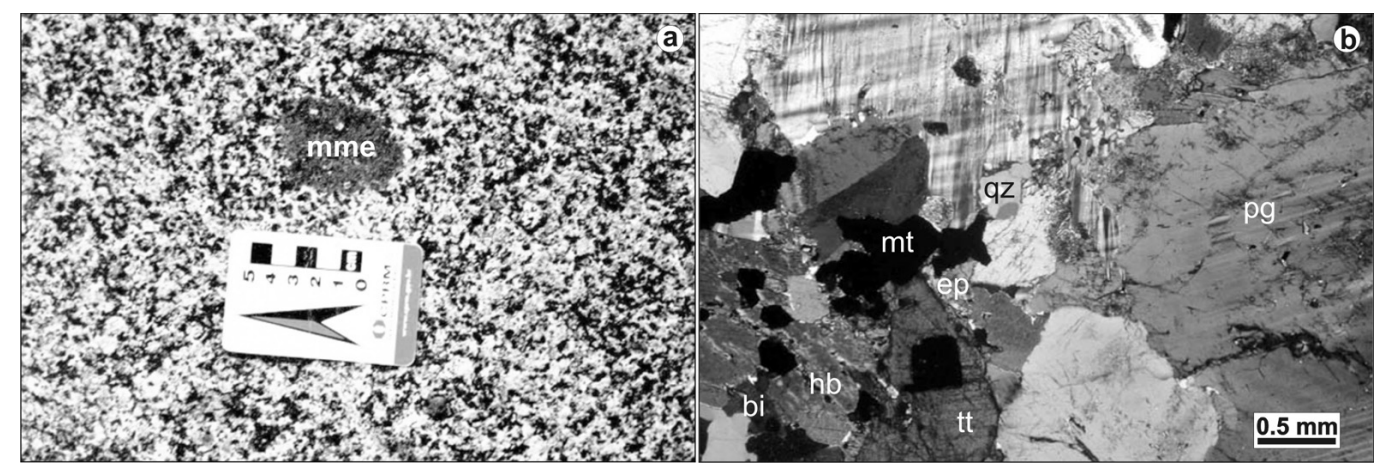

Figure 8 - Features of the Jaburuzinho facies from the Caroebe granite (outcrop MA-33): a) Hornblende-bearing tonalite showing rounded mafic clots and mafic microgranular enclave (mme); b) Photomicrography of mafic clots (bi. biotite, hb. hornblende, mt. magnetite, $t$ t. titanite and ep. epidote) and coarse-grained feldspars and quartz fine-medium grained (af. alkali feldspar, pg. plagioclase, qz. quartz, my. myrmekite) in quartz-monzodiorite (cross-polarized light, 2.5x).

magnetite: $0.7-4 \%)$, titanite (0.2-5\%), epidote, apatite, zircon and allanite. Muscovite and relicts of clinopyroxene are uncommon.

Plagioclase crystals are subhedral to euhedral, tabular, medium to coarse grained and shows strong to normal oscillatory zoning (Fig. 8b), which is well marked by saussuritization in the An-rich zones. Polysynthetic twinning is very common and eventually also occurs combined with carlsbad twinning. Desequilibrum features are locally present in partially corroded (irregular and embayment) rims. Subtle linear flow, parallel to that the mafic minerals (ENE-WSW to NE-SW), is also observed. Plagioclase enclosed by alkali feldspar megacrysts is subhedral, fine grained and shows subtle normal compositional zoning.

Two quartz textural types are observed: a) interstitial, anhedral, medium grained, and b) subhedral, fine to medium grained with slight ondulatory extinction. Under solid-sate deformation (local mylonitic zones), the quartz shows variable recrystallization stages. Normally, it shows fine grained subgrains outlining preserved ones, but granoblastic texture is also observed. Quartz ribbons are rare.

Microperthitic alkali feldspar megacrysts (Fig. $8 \mathrm{~b})$ are anhedral (locally interstitial), tabular and show several inclusions (plagioclase, drop-like quartz, biotite, apatite, opaque minerals). Likewise plagioclase megacrysts, they show an ENE-WSW flow foliation. Tartan twinning, occasionally combined with carlsbad twinning, is very common. Microfractures and myrmequite are scarce. Alkali feldspar is not very abundant in groundmass and shows subhedral, tabular (1:1 to $1: 2$ ), weak tartan twinning and rare inclusions. In the deformed types, these megacrysts are contourned by oriented mafic minerals and, in general, show coreand-mantle structure and microfractures (normally filled by quartz).

Biotite is straw yellow to greenish yellow, subhedral to euhedral, and shows strong to moderate pleocroism. It normally occurs in mafic clots associated with hornblende, titanite, epidote, opaque minerals and apatite (Fig. 8b). Apatite, zircon and primary epidote inclusions are very common. Biotite crystals occasionally are oriented, due to either by magma flow (most common) or to solid-state flow, both with similar direction (ENEWSW). Muscovite is uncommon and partially replaces biotite.

Hornblende is subhedral to euhedral, straw yellow, dark olive green to dark green and shows strong to moderate pleocroism. Few inclusions are observed, such as apatite, opaque minerals and minor titanite. Preserved clinopyroxene cores are very rare. Biotite and hornblende appear as rounded aggregates. Titanite is the most important accessory mineral in the Jaburuzinho facies. It occurs as euhedral to subhedral crystals, medium to coarse grained (Fig. 8b), and generally perfect losangle shape, associated to biotite, hornblende, opaque minerals and epidote in mafic clots. It also occurs as euhedral fine grained crystals, included in biotite, and anhedral grains bordering opaque minerals.

Alto Alegre facies The Alto Alegre facies is mainly composed of biotite monzogranites (around 80\%) with subordinated granodiorites, syenogranites and tonalites (Fig. 3a; Table 3). These granitoid rocks are generally isotropic, equigranular, medium- to coarse-grained, and eventually porphyrytic. The tabular alkali feldspar megacrysts are white to grayish and pale pinkish, showing 1 to $4 \mathrm{~cm}$ in length (ratio 3:1), 5 to 30\% (locally $50 \%$ ) in volume and ENE-WSW orientation (magma flow).

Similarly to the Jaburuzinho facies, the Alto Alegre facies shows some portions with anisotropic texture. Two anisotropic features are observed and may include remnants of the Jaburuzinho facies: a) oriented tabular megacrysts and lenticular mafic enclaves that indicate magma flow (predominate), and b) solid-state deformed minerals, including moderate recrystallization and mineral stretching. Both structures have ENE-WSW to NE-SW strikes, parallel to the regional trends. 
Table 3 - Modal mineral contents of samples from Caroebe granite. Modal analysis from (1) Sardinha (1999), (2) CPRM (2000) and (3) this paper. A. Alto Alegre and B. Jaburuzinho facies. Abbreviations: qz. quartz, af. alkali feldspar, pg. plagioclase, bi. biotite, amp. amphibole, ms. muscovite, tt. titanite, al. allanite, ep. epidote, zi. zircon, ap. apatite, om. opaque minerals, cpx. clinopyroxene, cl. chlorite, ss. saussurite, my. myrmequite, ph. prehnite, tr. trace, ref. references. *Água Branca granite (type-area).

\begin{tabular}{l|c|c|c|c|c|c|c|c|c|c|c|c|c|c|c|c|c|c|c|c}
\hline samples & classification & facies & $\mathrm{qz}$ & $\mathrm{af}$ & $\mathrm{pg}$ & $\mathrm{bi}$ & $\mathrm{amp}$ & $\mathrm{ms}$ & $\mathrm{tt}$ & $\mathrm{al}$ & $\mathrm{ep}$ & $\mathrm{zi}$ & $\mathrm{ap}$ & $\mathrm{om}$ & $\mathrm{cl}$ & $\mathrm{cpx}$ & $\mathrm{ss}$ & $\mathrm{my}$ & $\mathrm{ph}$ & $\mathrm{Ref}$ \\
\hline MA-276 & granodiorite & $\mathrm{A}$ & 31.2 & 7.8 & 45.6 & 7.5 & - & 0.3 & 1.5 & 0.6 & 0.9 & 0.3 & 0.3 & 0.9 & 0.3 & - & 2.7 & - & - & 3 \\
\hline MA 130A & monzogranite & $\mathrm{A}$ & 30.0 & 27.0 & 34.3 & 7.0 & - & - & 0.6 & 0.1 & 0.2 & 0.1 & 0.1 & 0.5 & 0.1 & - & - & - & - & 3 \\
\hline MA 124A & monzogranite & $\mathrm{A}$ & 29.5 & 38.0 & 23.3 & 8.0 & - & - & 0.2 & 0.1 & 0.1 & 0.1 & 0.1 & 0.5 & 0.1 & - & - & - & - & 3 \\
\hline MA-150 & granodiorite & $\mathrm{A}$ & 26.1 & 12.2 & 44.8 & 6.5 & - & 0.3 & 1.6 & - & 2.2 & 0.3 & tr & 1.6 & 0.5 & & 3.0 & 0.5 & 0.3 & 3 \\
\hline MA 120 & monzogranite & $\mathrm{A}$ & 26.0 & 35.0 & 25.5 & 12.0 & - & - & 0.5 & 0.1 & 0.3 & 0.1 & 0.1 & 0.3 & 0.1 & - & - & - & - & 3 \\
\hline MA 123 & monzogranite & $\mathrm{A}$ & 25.0 & 28.0 & 35.7 & 10.0 & - & 0.1 & - & - & 0.2 & 0.1 & 0.1 & 0.7 & 0.1 & - & - & - & - & 3 \\
\hline MJ 061C & monzogranite & $\mathrm{A}$ & 25.0 & 30.0 & 25.0 & 5.0 & - & 2.0 & 3.0 & - & 3.0 & - & 1.0 & 3.0 & 3.0 & - & - & - & - & 2 \\
\hline MA 053A & granodiorite & $\mathrm{A}$ & 23.6 & 20.3 & 38.9 & 9.9 & - & 0.8 & 0.4 & 0.3 & 1.7 & - & - & 1.1 & - & - & 1.9 & 1.1 & - & 3 \\
\hline MA-144A & granodiorite & $\mathrm{A}$ & 19.2 & 20.0 & 43.7 & 7.0 & - & - & 1.2 & 0.4 & 1.9 & 0.4 & 0.2 & 1.2 & - & - & 4.5 & 0.3 & - & 3 \\
\hline
\end{tabular}

\begin{tabular}{l|l|c|c|c|c|c|c|c|c|c|c|c|c|c|c|c|c|c|c|c}
\hline MA 104 & monzogranite & $\mathrm{B}$ & 30.0 & 34.5 & 23.0 & 6.0 & 5.0 & - & 0.1 & - & 0.1 & 0.1 & 0.1 & 1.0 & 0.1 & - & - & - & - & 3 \\
\hline MA 112 & monzogranite & $\mathrm{B}$ & 26.0 & 28.4 & 26.0 & 11.0 & 7.0 & - & 0.2 & 0.1 & 0.1 & 0.1 & 0.1 & 1.0 & - & - & - & - & - & 3 \\
\hline RL 006 & monzogranite & $\mathrm{B}$ & 20.6 & 29.2 & 36.2 & 11.8 & 0.6 & - & 0.4 & - & 0.1 & 0.1 & 0.2 & 0.7 & - & 0.1 & - & - & - & 1 \\
\hline HM-181* & monzogranite & - & 19.1 & 27.4 & 34.1 & 8.4 & 2.7 & - & 0.3 & - & 2.1 & 0.5 & 0.2 & 1.0 & - & - & 3.3 & 0.5 & - & 3 \\
\hline MA 053C & tonalite & $\mathrm{B}$ & 16.3 & 4.9 & 42.7 & 19.9 & 7.0 & 0.4 & 0.8 & 0.1 & 1.5 & 0.1 & 0.1 & 1.2 & 0.1 & - & 4.7 & 0.2 & - & 3 \\
\hline MA 121 & $\begin{array}{l}\text { quartz } \\
\text { monzodiorite }\end{array}$ & $\mathrm{B}$ & 15.8 & 14.5 & 54.0 & 9.7 & 2.3 & 0.1 & 1.1 & 0.1 & 0.8 & 0.2 & 0.2 & 1.1 & 0.1 & - & - & - & - & 3 \\
\hline MA 103 & granodiorite & $\mathrm{B}$ & 15.0 & 12.0 & 43.0 & 10.0 & 12.0 & - & 0.6 & - & 0.6 & 0.1 & 0.1 & 1.7 & 0.1 & 4.8 & - & - & - & 3 \\
\hline MA-187 & $\begin{array}{l}\text { quartz } \\
\text { monzodiorite }\end{array}$ & $\mathrm{B}$ & 14.9 & 9.5 & 48.9 & 11.2 & 3.4 & 0.0 & 3.2 & tr & 1.7 & 0.0 & 0.3 & 2.3 & 0.6 & - & 3.2 & 0.9 & - & 3 \\
\hline MA 053B & quartz monzonite & $\mathrm{B}$ & 14.2 & 30.4 & 38.3 & 12.1 & 0.3 & 0.3 & 0.4 & - & 0.6 & 0.1 & 0.2 & 1.9 & 0.2 & - & 0.6 & 0.4 & - & 3 \\
\hline MF 068A & $\begin{array}{l}\text { quartz } \\
\text { monzodiorite }\end{array}$ & $\mathrm{B}$ & 10.0 & 14.0 & 35.0 & 10.0 & 8.0 & 2.0 & 2.0 & - & 2.0 & - & 3.0 & 4.0 & 2.0 & 7.0 & 1.0 & - & - & 2 \\
\hline MJ 061B & quartz monzonite & $\mathrm{B}$ & 9.0 & 23.0 & 37.0 & 6.0 & 16.0 & 1.0 & 2.0 & - & 1.0 & - & 2.0 & 1.0 & 2.0 & - & - & - & - & 2 \\
\hline MA-178B & $\begin{array}{l}\text { quartz } \\
\text { monzodiorite }\end{array}$ & $\mathrm{B}$ & 7.2 & 9.3 & 42.5 & 14.7 & 9.3 & - & 1.8 & - & 4.8 & 0.7 & 0.9 & 3.6 & - & - & 3.8 & 1.4 & - & 3 \\
\hline MF 073C & quartz diorite & $\mathrm{B}$ & 5.0 & 2.0 & 26.0 & 14.0 & 37.0 & 2.0 & 5.0 & - & 2.0 & - & 2.0 & 4.0 & 1.0 & - & - & - & - & 2 \\
\hline MA-144B & quartz diorite & $\mathrm{B}$ & 4.1 & 1.9 & 44.2 & 18.0 & 13.5 & - & 4.4 & - & 3.3 & 0.6 & 0.6 & 3.0 & - & - & 6.6 & - & - & 3 \\
\hline
\end{tabular}

The Alto Alegre granitoid rocks enclose hornblende-bearing microgranular enclaves (dioritic to granodioritic in composition) mainly near Jaburuzinho facies boundaries. These enclaves have $5 \mathrm{~cm}$ to $20 \mathrm{~m}$ in length and are elliptical, slightly rounded (Fig. 9a) and elongate (Fig. 9g), locally with irregular and wispy terminations (Fig. 9c).

Felsic coarse-grained monzogranite enclaves are also enclosed by the Alto Alegre granitoid rocks. These enclaves are equigranular, pale gray, circular, rounded (Fig. 9a, b and c), irregular, elongate or angular (Fig. 9d, f and, h), showing linear orientation (Fig. 9b and f). These three magmatic phases (Alto Alegre granitoid rocks, hornblende-bearing enclaves related to Jaburuzinho facies and felsic coarse-grained monzogranite enclaves) show a complex physical interaction (Fig. 9h), but chemical effects are also possible (Almeida and Macambira 2003).

The angular and rounded forms observed in the felsic monzogranite enclaves suggest different stages of assimilation. The contacts are sharp and chilled margins are not recorded. On the other hand, the hornblendebearing enclaves show lobate to crenulate (flame-like) contacts with host monzogranite to granodiorite (Fig. 9c), locally with "dropped" megacrysts, which suggests that the amount of liquid was high at the time of emplacement. In detail, the boundaries of these enclaves reproduce the overall contacts with the host granitoid rock (mimetization or ghost structures), suggesting a probable incomplete mingling process. Furthermore, the abundance of elongate to rounded enclaves and net veining in the mafic enclaves by the host granitoid rock, both suggest according to Vernon et al. (1988) mingling and/or mixing of magmas at the site of emplacement.

In this sense, only one outcrop of the Alto Alegre facies record field features of magma mixing. The possible mixing magma conduit has nearly $2 \mathrm{~m}$ of length and shows strong to extreme elongate enclaves (Fig. 9g and $\mathrm{h}$ ) in which the distortion has been accomplished by magmatic flow without solid state deformation, as evidenced by strong orientation of the minerals, coupled with lack of microstructural evidence of intergranular plastic strain (Vernon et al. 1988).

The Alto Alegre granitoid rocks show mineral assemblage (Table 3) composed of plagioclase (23-46 $\%$ ), quartz (19-31\%), alkali feldspar (15-38\%), biotite (5-12\%), minor titanite, opaque minerals, epidote, apatite, allanite and zircon. In some samples muscovite 
also replaces biotite. The mafic mineral content is quite variable (Fig. 3b) and has biotite as the main mafic mineral.

Plagioclase is tabular, subhedral to euhedral, medium to coarse grained, locally as megacrysts showing combined polysynthetic and Carlsbad twinning. These crystals exhibit normal (mainly) to oscillatory compositional zoning, which stands out optically by secondary alteration (saussuritization) in the An-rich portions. Some megacrysts are irregular and show embayed rims in contact with alkali feldspar grains. Quartz is heterogranular, anhedral, and sometimes occurs as monocrystalline aggregates. Inclusions of drop-like quartz are also very common in the alkali feldspar megacrysts. Locally, it shows ondulatory extinction and dynamic (fine grained subgrains) to static recrystallization (granoblastic texture) effects in the solid-state deformed types.

Alkali feldspar shows two main generations. The first type is characterized by fine grained crystals with euhedral to subhedral shapes and tartan twinning in the groundmass. The second generation is marked by anhedral perthitic and poikilitic megacrysts encompassing several inclusions (biotite, drop-like quartz, plagioclase and first generation alkali feldspar). In the solid-state deformed types, the alkali feldspar megacrysts are contoured by biotite trails, showing core-and-mantle structure and eventually granoblastic texture, suggesting upper greenschist to amphibolitefacies conditions.

Biotite is subhedral, medium grained, moderately pleocroic, and straw yellow to yellow greenish. Normally, it forms crystal aggregates and has apatite, epidote, allanite, zircon and opaque mineral inclusions, generally occurring as circular or irregular mafic clots. Locally, it is slightly to strongly oriented; some crystals are partially altered into muscovite. Titanite is medium to fine grained, euhedral, showing diamond shape or anhedral grains bordering opaque minerals.

IGARAPÉ AZUL GRANITE Based on petrographic (e.g. muscovite presence) and chemical (peraluminous character) parameters, Faria et al. (1999) individualized a portion of the Água Branca suite as a new granitic body that they called Igarapé Azul granite, initially interpreted as an S-type granite. The Igarapé Azul granite was revisited by Almeida et al. (2002) who noted that Stype granitoid rocks in southeast Roraima are restricted to the Serra Dourada region and not in the Igarapé Azul type-area.

In the type-area the Igarapé Azul granite is characterized only by (muscovite)-biotite leucomonzogranites and monzogranites to rare syenogranites and granodiorites, generally with low mafic contents (Fig. $3 \mathrm{~b}$ ), showing a compositional field in the QAP diagram similar to granites of crustal origin (e.g. Lameyre and Bowden 1982, Lameyre and Bonin 1991, Fig. 3a, Table 4), but no aluminous diagnostic minerals are described. The main granitic body has $1120 \mathrm{~km}^{2}$ and shows also an important textural asymmetric zoning with three main granitic facies: Vila Catarina, Saramandaia and Cinco Estrelas (Fig. 2). Other minor correlated granitic bodies have around $30 \mathrm{~km}^{2}$ to $125 \mathrm{~km}^{2}$. Thus, all granitic bodies with these same characteristics must be grouped in the Igarapé Azul Intrusive Suite (this paper).

Common petrographic features Despite local textural variations, all facies of the batholith have similar composition (mainly monzogranite and minor granodiorite to syenogranite) and mineral assemblages, including accessory (epidote, allanite, opaque minerals, zircon and apatite) and secondary minerals (epidote, chlorite and muscovite).

Subhedral and tabular plagioclase are medium to fine-grained, show polyssinthetic twinning and normal zoning. Locally, its nucleus is partially altered to epidote and minor sericite and chlorite. Euhedral megacrysts are rare and eventually show oscillatory zoning, biotite inclusion and preferred orientation. Anhedral crystals with embayment are also observed and sometimes they show obliterated zoning and twinning. Quartz is fine to coarse-grained, anhedral, sometimes interstitial, locally fractured with ondulatory extinction and partially recrystallized (subgrains).

Alkali feldspar is partially altered to sericite and muscovite, and occurs as two different types: a) subhedral to anhedral, fine to coarse grained (3-8 mm long), tabular crystals showing tartan twinning, rarely combined with carlsbad twinning; b) tabular, anhedral and microperthitic megacrysts (25-40 $\mathrm{mm}$ long), locally with embayed rims and drop-like quartz, very altered plagioclase, biotite and locally opaque minerals and epidote inclusions. Myrmekite intergrowth is also common.

Subhedral biotite is fine to coarse grained, moderate to strongly pleocroic and straw yellow to brown greenish. Biotite with red brownish color is very uncommon. Eventually it occurs as mafic clots associated to epidote and/or allanite, opaque mineral, zircon and apatite. In general, it is slightly oriented and some crystals are partially or totally replaced by muscovite and/or chlorite.

Epidote is the main accessory mineral in the Igarapé Azul granite. The crystals are fine to medium grain size, subhedral to euhedral shapes, pale yellow to pale green and locally zoned, showing cores of allanite. Anhedral crystals are commonly observed as inclusions in plagioclase. Metamitic allanite shows pale brown to orangish brown colors. Twinned crystals are uncommon. Sulfides and oxides are subhedral to euhedral, fined to medium-grained and show hexagonal and square habits, normally associated with biotite. Rarely they show anhedral and interstitial forms.

These petrographic characteristics in commom represent transitional features among nucleus and margins facies of the Igarapé Azul pluton. This granite shows textural differences only (e.g. feldspar megacrysts modal volume and groundmass grain-size), suggesting local $\mathrm{P}_{\mathrm{H} 2 \mathrm{O}}$ variations. 


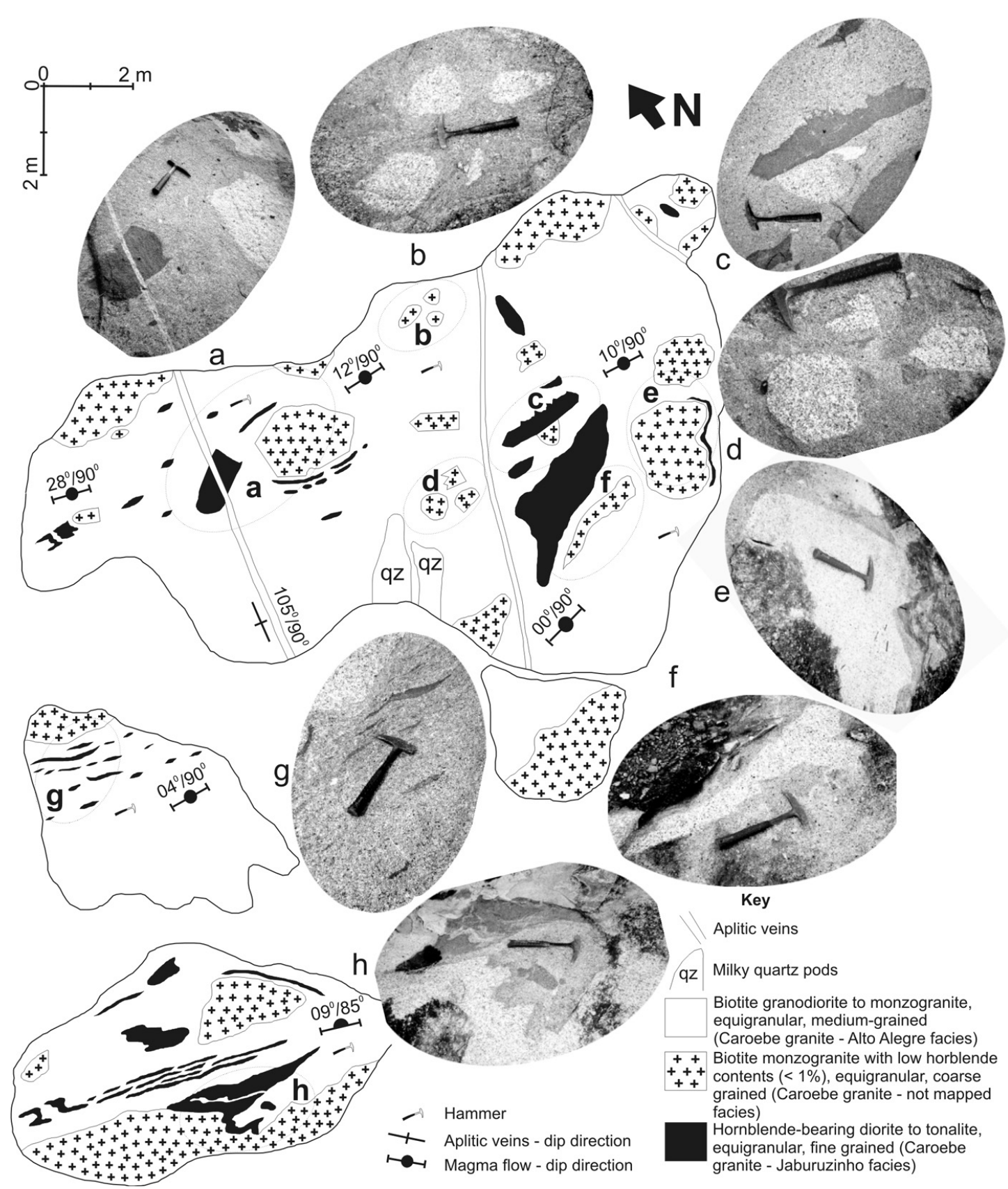

Figure 9 - Characteristics of the Alto Alegre facies of the Caroebe granite (outcrop MA-53). See text for details.

Vila Catarina facies The Vila Catarina facies has nearly $340 \mathrm{~km}^{2}$ and occurs in the center-western portion of the Igarapé Azul granite, showing several NbTa alluvial mineral occurrences, including abundant aplitic to pegmatitic dikes. It has also similar structural trend (NE-SW) to that observed in Cinco Estrelas facies described below.

The Vila Catarina granitoid rocks are characterized by mainly monzogranites and restrict syenogranite (Fig. 3a) pale gray to pale pink, showing equigranular to slightly porphyrytic $(<5 \%$ alkali feldspar megacrysts), medium to coarse-grained texture and variable mafic mineral content (always $<10 \%$ ). In thin section, the groundmass is granular, anhedral and, locally, encompasses alkali feldspar megacrysts ( 1.5 to $2.0 \mathrm{~cm}$ long) and mafic clots. The mineral assemblage (Table 4) is composed of plagioclase (24-45\%), quartz (21-38\%), alkali feldspar (20-41\%), biotite (0.6-8 $\%)$, locally transformed into muscovite $(0.2-2 \%)$, and opaque minerals, epidote, allanite, zircon and apatite. The most important secondary minerals are epidote, chlorite and titanite.

Saramandaia facies The Saramandaia facies has nearly $735 \mathrm{~km}^{2}$ in area and occurs in the northern portion of the batholith. This granitoid rock is cross-cut by 
dykes and blobs of the Cinco Estrelas and Vila Catarina facies. In the Saramandaia facies, the granitoid rocks have porphyrytic texture showing alkali feldspar megacrysts ( $5 \%$ to $20 \%)$ with heterogeneous size $(<1$ to 5 $\mathrm{cm}$ long) and spatial distribution (Fig. 10a,b), similar to those of the Vila Catarina facies. These megacrysts are microperthitic, tabular, euhedral, white to slightly pinkish and eventually are oriented due to magma flow. They are enveloped by homogeneous and medium grained groundmass of monzogranitic to granodioritic composition.

The megacryst direction is locally outlined by ellipsoidal biotite-bearing enclaves, following ENEWSW to NE-SW-trends. Similar trends are observed in the megacryst direction of the Caroebe granitoid rocks that are also subparallel to the regional foliation strikes observed in the host Martins Pereira granitoid rock. However, the low amount of megacrysts makes this flow to be almost imperceptible.

In this facies, monzogranites are dominant;
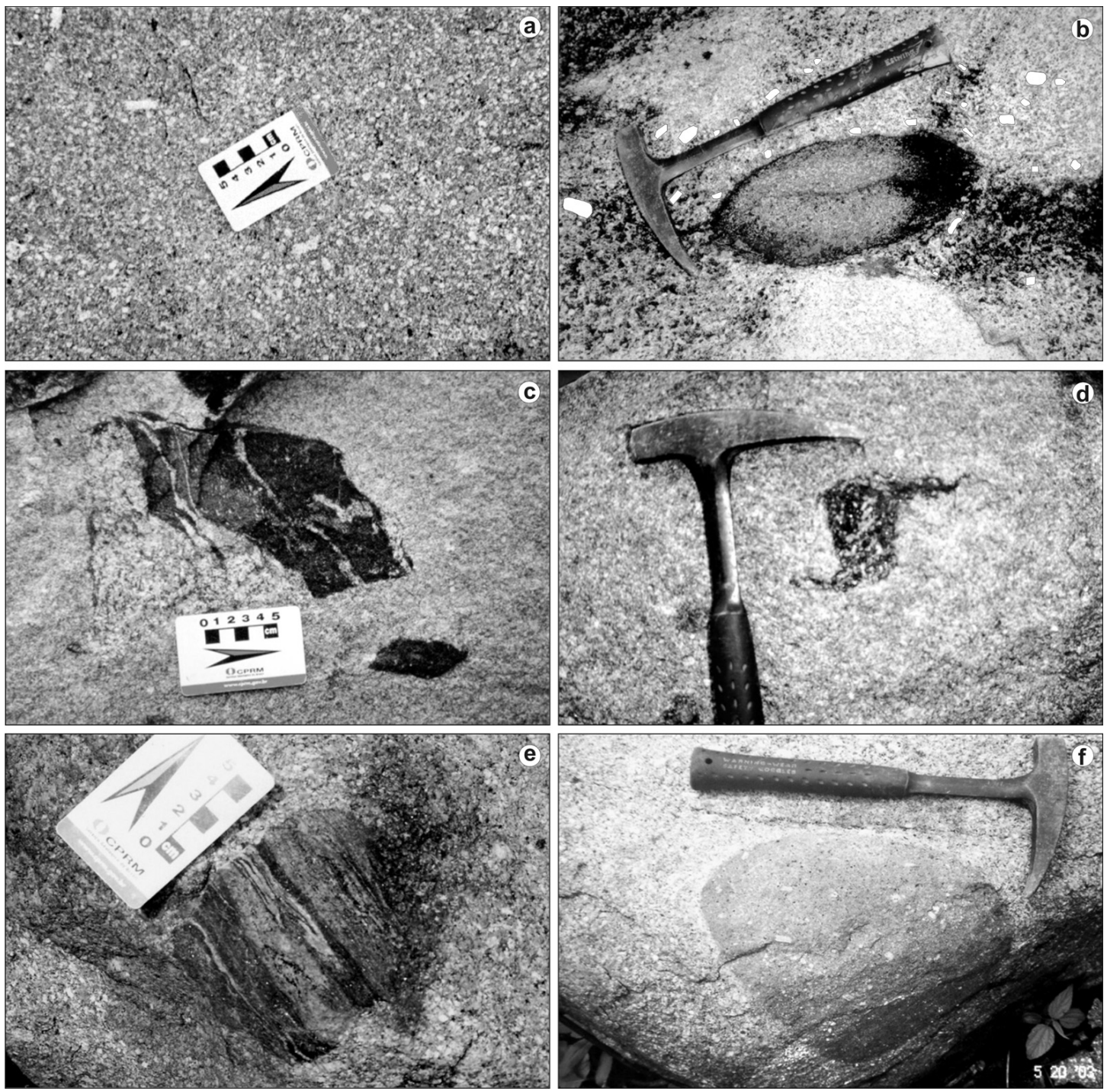

Figure 10 - Igarapé Azul granite outcrops: a) Slightly porphyrytic biotite monzogranite (Saramandaia facies) showing tabular alkali feldspar megacrysts with approximately N600W strike magma flow (outcrop MA-322); b) Tabular alkali feldspar megacrysts in leucogranodiorite (Saramandaia facies) turning around elliptical tonalite gneiss enclave (outcrop MA-213); c) Irregular biotite-rich diorite gneiss enclave showing fine grained equigranular texture surrounded by biotite leucomonzogranite (Cinco Estrelas facies). Note that the host granite fill the enclave foliation planes (outcrop MA-147); d) Porphyrytic biotite granodiorite enclave (Martins Pereira granite) enclosed by the Igarapé Azul granite (Cinco Estrelas facies). The enclave is rotated and biotite trails are observed in its extremities (outcrop MA-99). e) Rounded paragneiss enclave showing strong compositional layering and local growing of biotite and muscovite (outcrop MA-322). f) Rounded and circular mafic microgranular enclave with porphyrytic texture (outcrop MA-322). 
Table 4 - Modal mineral contents of Igarapé Azul granite and their enclaves. Modal analysis from (1) Sardinha (1999), (2) CPRM (2000) and (3) this paper. A. Cinco Estrelas, B. Saramandaia, C. Vila Catarina, D. biotite-bearing enclave. Abbreviations: qz. quartz, af. alkali feldspar, pg. plagioclase, bi. biotite, ms. muscovite, tt. titanite, al. allanite, ep. epidote, zi. zircon, ap. apatite, om. opaque minerals, cl. chlorite, lx. leucoxene, ss. saussurite, my. myrmequite, tr. trace, ref. references.

\begin{tabular}{l|l|c|c|c|c|c|c|c|c|c|c|c|c|c|c|c|c|c}
\hline samples & \multicolumn{1}{|c}{ classification } & facies & $\mathrm{qz}$ & $\mathrm{af}$ & $\mathrm{pg}$ & $\mathrm{bi}$ & $\mathrm{ms}$ & $\mathrm{tt}$ & $\mathrm{al}$ & $\mathrm{ep}$ & $\mathrm{zi}$ & $\mathrm{ap}$ & $\mathrm{om}$ & $\mathrm{cl}$ & $\mathrm{lx}$ & $\mathrm{ss}$ & $\mathrm{my}$ & $\mathrm{Ref}$ \\
\hline MA 088 & syenogranite & $\mathrm{A}$ & 38.0 & 36.4 & 11.3 & 4.5 & 4.6 & 0.2 & 1.0 & 1.1 & 0.1 & - & 0.7 & 0.6 & - & 1.5 & - & 3 \\
\hline MJ 018 & leucomonzogranite & $\mathrm{A}$ & 35.3 & 31.1 & 27.9 & 3.0 & 1.4 & 0.1 & 0.1 & 0.3 & 0.1 & 0.1 & 0.5 & 0.1 & - & - & - & 1 \\
\hline RL 010 & leucogranodiorite & $\mathrm{A}$ & 33.7 & 18.2 & 41.5 & 4.0 & 0.1 & 0.2 & 0.1 & 0.4 & 0.1 & 0.1 & 1.0 & 0.1 & - & 0.5 & - & 1 \\
\hline NR 013 & leucomonzogranite & $\mathrm{A}$ & 32.2 & 30.8 & 32.1 & 2.2 & - & 0.1 & 0.1 & 0.6 & 0.1 & 0.1 & 1.4 & 0.2 & 0.2 & - & - & 1 \\
\hline RL 007B & leucomonzogranite & $\mathrm{A}$ & 32.0 & 26.1 & 36.6 & 3.6 & - & 0.1 & 0.1 & 0.4 & 0.1 & 0.1 & 0.9 & 0.1 & 0.1 & 0.3 & - & 1 \\
\hline MF 014 & leucogranodiorite & $\mathrm{A}$ & 30.0 & 21.6 & 44.5 & 2.3 & 0.9 & - & - & 0.1 & 0.1 & - & 0.1 & 0.3 & 0.1 & - & - & 1 \\
\hline RL 009B & leucomonzogranite & $\mathrm{A}$ & 28.5 & 24.0 & 43.1 & 2.8 & - & 0.1 & - & 0.4 & 0.1 & 0.1 & 0.5 & 0.1 & 0.2 & 0.5 & - & 1 \\
\hline MF 006C & leucogranodiorite & $\mathrm{A}$ & 25.6 & 17.7 & 52.0 & 3.5 & 0.2 & 0.2 & 0.1 & 0.1 & 0.1 & 0.1 & 0.4 & 0.3 & - & - & - & 1 \\
\hline MA 147A & monzogranite & $\mathrm{A}$ & 24.6 & 31.8 & 24.2 & 1.3 & 1.9 & 0.1 & 0.1 & 4.6 & 0.1 & 0.1 & 1.0 & 3.4 & - & 6.1 & 0.7 & 3 \\
\hline MF 006B & leucomonzogranite & $\mathrm{A}$ & 23.0 & 31.3 & 42.7 & 1.4 & - & 0.1 & - & 0.1 & 0.1 & 0.1 & 0.7 & 0.6 & - & - & - & 1 \\
\hline MA 079 & quartz monzonite & $\mathrm{A}$ & 16.0 & 25.0 & 33.7 & 9.5 & 2.4 & 0.3 & - & 1.5 & - & - & 1.0 & 0.2 & - & 9.5 & 0.9 & 3 \\
\hline
\end{tabular}

\begin{tabular}{l|l|c|c|c|c|c|c|c|c|c|c|c|c|c|c|c|c|c}
\hline RL 011 & monzogranite & $\mathrm{B}$ & 33.0 & 27.0 & 32.0 & 5.7 & 0.6 & 0.3 & 0.1 & 0.4 & 0.1 & 0.1 & 0.6 & 0.1 & - & - & - & 1 \\
\hline MJ 014 & monzogranite & $\mathrm{B}$ & 30.6 & 25.2 & 37.3 & 4.8 & 0.6 & 0.1 & 0.1 & 0.4 & 0.1 & 0.1 & 0.7 & - & - & - & - & 1 \\
\hline MJ 017B & leucogranodiorite & $\mathrm{B}$ & 30.2 & 23.3 & 44.1 & 0.4 & 0.2 & 0.1 & - & 0.7 & 0.1 & 0.1 & 0.4 & 0.4 & - & - & - & 1 \\
\hline MA 186A & monzogranite & $\mathrm{B}$ & 29.0 & 27.9 & 26.4 & 4.6 & 1.0 & - & - & 1.1 & - & - & 0.9 & 0.2 & - & 7.9 & 1.0 & 3 \\
\hline MA 201A & monzogranite & $\mathrm{B}$ & 25.8 & 25.1 & 31.6 & 3.9 & 0.3 & - & - & 1.5 & 0.1 & 0.2 & 0.3 & 0.2 & - & 10.5 & 0.5 & 3 \\
\hline MJ 017A & leucomonzogranite & $\mathrm{B}$ & 24.3 & 28.6 & 41.5 & 3.6 & 0.2 & 0.1 & 0.1 & 0.2 & 0.1 & 0.1 & 0.5 & 0.8 & - & - & - & 1 \\
\hline
\end{tabular}

\begin{tabular}{l|l|c|c|c|c|c|c|c|c|c|c|c|c|c|c|c|c|c}
\hline MF 006A & leucogranodiorite & $\mathrm{C}$ & 38.1 & 20.1 & 39.6 & 1.4 & tr & - & - & 0.1 & 0.1 & 0.1 & 0.3 & 0.1 & 0.1 & - & - & 1 \\
\hline MA 002 & leucomonzogranite & $\mathrm{C}$ & 30.5 & 29.1 & 33.0 & 2.5 & 0.4 & 0.2 & 0.2 & 0.6 & 0.1 & - & 0.8 & 0.3 & - & 1.2 & 1.1 & 3 \\
\hline RL 008 & monzogranite & $\mathrm{C}$ & 30.3 & 24.0 & 35.9 & 7.9 & 0.5 & 0.1 & - & 0.6 & 0.1 & 0.1 & 0.5 & - & - & - & - & 1 \\
\hline RL 009A & monzogranite & $\mathrm{C}$ & 29.2 & 30.5 & 33.7 & 4.5 & 0.2 & 0.1 & 0.1 & 0.5 & 0.1 & 0.1 & 0.7 & 0.1 & 0.1 & 0.1 & - & 1 \\
\hline MF 010B & monzogranite & $\mathrm{C}$ & 27.5 & 37.7 & 24.3 & 7.2 & 1.6 & 0.1 & - & 0.4 & 0.1 & 0.2 & 0.6 & 0.3 & - & - & - & 1 \\
\hline MJ 012 & monzogranite & $\mathrm{C}$ & 26.4 & 23.7 & 41.0 & 6.9 & 0.5 & 0.2 & 0.1 & 0.4 & 0.1 & 0.1 & 0.3 & - & - & 0.3 & - & 1 \\
\hline MJ 015B & monzogranite & $\mathrm{C}$ & 25.8 & 40.5 & 24.0 & 6.0 & 1.5 & 0.1 & - & 0.3 & 0.1 & 0.1 & 0.4 & 0.2 & - & 1.0 & - & 1 \\
\hline MA 102A & leucomonzogranite & $\mathrm{C}$ & 22.9 & 28.7 & 36.8 & 0.6 & 0.7 & 0.1 & 0.3 & 1.0 & 0.1 & - & 1.1 & 0.2 & - & 6.4 & 1.1 & 3 \\
\hline MF 079 & monzogranite & $\mathrm{C}$ & 21.2 & 26.1 & 44.7 & 6.2 & tr & 0.1 & 0.4 & 0.1 & 0.1 & 0.1 & 1.0 & - & - & - & - & 1 \\
\hline
\end{tabular}

\begin{tabular}{l|c|c|c|c|c|c|c|c|c|c|c|c|c|c|c|c|c|c}
\hline MA-085B & granodiorite & $\mathrm{D}$ & 12.9 & 8.8 & 34.1 & 27.6 & - & 0.6 & - & 1.2 & 0.6 & 1.2 & 4.7 & 1.2 & - & 5.9 & 1.2 & 3 \\
\hline MA 186B & tonalite & $\mathrm{D}$ & 9.0 & 0.1 & 20.0 & 55.0 & 10.0 & - & - & 4.7 & 0.1 & 0.1 & 1.0 & - & - & - & - & 3 \\
\hline MA 213B & quartz monzodiorite & $\mathrm{D}$ & 6.0 & 3.0 & 40.0 & 46.0 & 2.0 & - & - & tr & tr & 0.1 & 2.9 & - & - & - & - & 3 \\
\hline MA 147B & quartz diorite & $\mathrm{D}$ & 5.0 & 0.1 & 39.0 & 49.7 & 2.0 & 0.1 & 0.1 & 1.1 & 0.1 & 0.1 & 2.7 & - & - & - & - & 3 \\
\hline MA 201B & quartz diorite & $\mathrm{D}$ & 4.4 & 7.0 & 12.5 & 57.7 & 6.3 & 0.2 & - & 0.4 & 0.7 & 1.5 & 6.7 & 0.4 & - & 2.1 & 0.1 & 3 \\
\hline
\end{tabular}

granodiorites are subordinated (Fig. 3a) as well as leucogranites. The mineral assemblage (Table 4 ) is composed by plagioclase $(26-44 \%)$, quartz $(24.3-33.0 \%)$, alkali feldspar (23.3-28.6 \%), biotite (0.4-5.7\%), muscovite (0.2-1.0\%), opaque minerals, primary epidote, allanite, and minor zircon and apatite. Epidote, chlorite and, exceptionally titanite, are the main secondary minerals in the Saramandaia facies.

Cinco Estrelas facies The Cinco Estrelas facies has $445 \mathrm{~km}^{2}$, located at the easternmost portion of the Igarapé Azul batholith, showing granitoid rocks with very low mafic contents, and equigranular, homogeneous and fine to medium-grained texture (Figs. 10c,d). These granitoid rocks are also whitish gray, monzogranitic in composition with subordinated syenogranite, granodiorite and quartz monzonite (Fig. 3a). They are emplaced according to a NE-SW structural direction and locally also occur as blobs and dikes subconcordant with magma flow direction, as observed in the porphyrytic types of the Saramandaia facies.

The Cinco Estrelas facies mineral assemblage (Table 4) is composed by plagioclase (11-52\%), quartz (16-38 \%), alkali feldspar (18-36\%), biotite (1-5\%), totally or partially transformed into muscovite $(0.1-5$ $\%$ ), and opaque minerals, allanite, primary epidote, zircon and apatite. The most important secondary minerals are epidote, chlorite and leucoxene.

Enclaves The enclaves found in the Igarapé Azul granitoid rocks are dominantly biotite-rich (Table 4) with fine to coarse-grained muscovite crystals. These enclaves show sharp and irregular (Fig. 10c) to elliptical (Fig. 10b) shapes, locally with gneissic texture. Several enclaves have also elongated shapes and biotite trails and schlieren only. In general, these enclaves are 
parallel to the magma flow defined by alkali feldspar megacrysts in the host granitoid rocks (Fig. 10b). The contact enclaves-host granitoid rock is normally sharp, however, sometimes it shows transitional and gradational features.

The biotite-bearing enclaves show quartz dioritic, tonalitic and quartz monzodioritic compositions (Fig. 3a, Table 4), equigranular fine to coarse grained texture, and black to gray colors. They also show foliation defined by biotite and muscovite (Fig. 11 ), but it is not always observed at naked eye. Its mineral assemblage is composed by biotite (27.6-57.7 $\%)$, plagioclase (12.5-40.0\%), muscovite $(2.0-10.0$ $\%)$, quartz (4.4-12.9\%), alkali feldspar (0.1-12.9\%), epidote (0.4-4.7\%) and opaque minerals (1.0-6.7\%). Other minerals are rare, such as titanite, apatite, zircon and allanite. Secondary epidote and sericite are common.

Subhedral biotite is fine to coarse grained, brown greenish to straw yellow, locally reddish brown, and moderately pleocroic. Inclusions such as zircon, apatite, epidote, and occasionally allanite, are common. Muscovite is also subhedral, fine to medium-grained and aligned at the same direction of biotite. Large individual crystals is intergrowth or replacing biotite. Plagioclase shows two crystal generations: a) coarse grained (eventually megacrysts), subhedral to anhedral (embayed contacts are very common), slight ondulatory extinction, normal zoning (rarely oscillatory) with calcic zones steeply replaced by epidote, carbonate and minor sericite; b) fine to medium grained, subhedral to euhedral, tabular, clear polyssinthetic twinning and rarely replaced by secondary minerals. Fine to medium-grained subhedral quartz has ondulatory extinction and locally shows dynamic recrystallization features. Subhedral to anhedral alkali feldspar is very uncommon. Subhedral epidote and allanite occurs as inclusion in biotite and plagioclase crystals. Opaque minerals occur as euhedral and tabular crystals and titanite is rare, eplacing calcic portions of plagioclase cores, and biotite cleavages. Locally, titanite occurs as subhedral, fine to medium-grained and isolate crystals.

Other enclaves are subordinated within the Igarapé Azul granite. Xenoliths similar to the Martins Pereira granitoid rocks (Fig. 10d) and Cauarane paragneiss with preserved banding (Fig. 10e) are rotated, rounded and partially modified, with local "migmatitic" features, suggesting local assimilation by the host rock. Mafic (porphyrytic) microgranular enclaves (Fig 10f) are observed only locally.

A-type granites In general, the A-type granites in the southern Roraima and northern Amazonas states crosscut the basement rocks during two main magmatic events (Costi et al. 2000, CPRM 2000, 2003): AbonariMapuera (1.88-1.86 Ga) and Moderna-Madeira (1.82$1.79 \mathrm{Ga})$ granitic episodes. The interval ages are determined mainly by single-zircon $\mathrm{Pb}$ evaporation and zircon U-Pb SHRIMP methods.

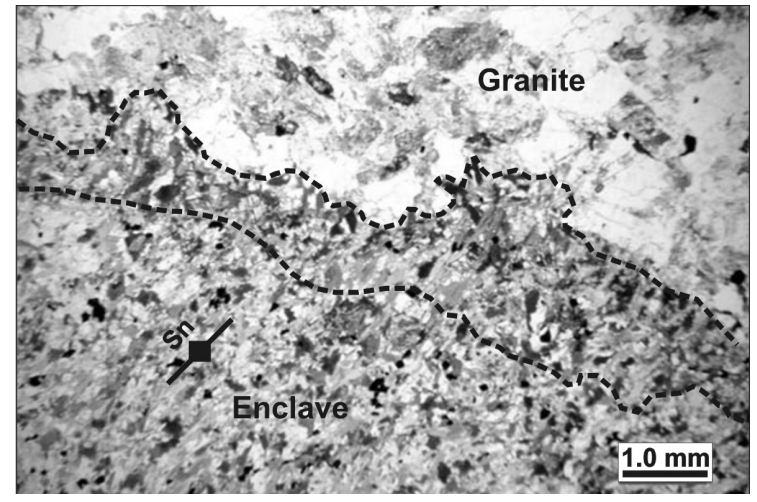

Figure 11 - Photomicrography showing graniteenclave contact. Dashed lines show the growing and high concentration of biotite crystals from the biotite-bearing gneissic enclave (quartz dioritic) close to the contact with isotropic leucomonzogranite (Igarapé Azul Granite, Cinco Estrelas facies). This biotite grain size increasing is probably due to static recrystallization related to the high thermal gradient among host-enclave. The enclave foliation (Sn) is also showed. Parallel-polarized light (1.25x).

\section{MAPUERA GRANITE AND COEVAL GRANITOID}

ROCKS The Mapuera A-type granites (CPRM 2000, 2003) and coeval granitoid rocks occur at the south and southeast of the studied area (Fig. 2), in the Jauaperi and Murauaú rivers, showing biotite only as the mafic mineral. Three main granitic bodies were observed. The first one has $46 \mathrm{~km}^{2}$ and occurs near to the São João da Baliza and São Luís do Anauá towns at the Jauaperi river basin. It shows monzogranitic to syenogranitic composition, porphyrytic texture (locally with ovoid megacrysts) and coarse to medium grain size. The second granitic body has $49 \mathrm{~km}^{2}$ and occurs along the Murauaú River, being composed of monzogranites with equigranular to slightly porphyrytic texture, and medium grain size. Locally in the northern portion it is steeply deformed by NE-SW dextral shear zones. The Serra do Itã granite $\left(520 \mathrm{~km}^{2}\right.$ in area) has E-W trend emplaced near the Itã fault zone and in the headwaters of the Anauá, Dias and Pedras rivers.

The mineral assemblage is represented by microperthitic alkali feldspar, plagioclase (eventually bordered by alkali feldspar), quartz and biotite, this last one in association with accessory minerals such as titanite, zircon, apatite, opaque minerals and rarelly allanite, fluorite and garnet. Locally quartz and feldspars show ondulatory extinction and dynamic recrystallization. Granophyric texture and myrmekite are also commom. Secondary minerals are sericite (and muscovite), chlorite, epidote and clay-minerals.

MODERNA GRANITE AND COEVAL GRANITOID ROCKS The Moderna (Santos et al. 1997) and coeval granitoid rocks (Fig. 2) are dominantly monzogranite to syenogranite, rarely alkali feldspar granite in composition, showing pale pink to pale gray colors, 
equigranular to slightly porphyrytic texture, coarse grain size and amphibole (hastingsite) and biotite mafic clots. Paragneissic xenoliths of the Cauarane Group and pegmatitic and amethyst-bearing quartz veins are also observed.

At least, four granitic bodies related to the Moderna-Madeira granitic episode, all structurallycontroled by NW-SE trends, were mapped by aerogeophysical airbone and radar images: 1) the type-area of the Moderna granite occurs near the Moderna town, and has two main plutonic bodies of $51 \mathrm{~km}^{2}$ and $15 \mathrm{~km}^{2}$ controlled by a NW-SE structure; 2) Serra da Tentativa granite has $58 \mathrm{~km}^{2}$ and crops out in the Jaburuzinho river; 3) Igarapé do Banho granite shows $210 \mathrm{~km}$, cross-cuted by E-W dextral shear zones; and 4) northern Caroebe granite has $330 \mathrm{~km}^{2}$ and is also structurally controlled by an NW-SE trend.

The mineral assemblage shows microperthitic alkali feldspar, albite, plagioclase (oligoclase), quartz, biotite and amphibole (intersticial hastingsite with local clinopyroxene relics). The accessory minerals are opaque minerals, apatite, zircon, allanite, titanite (intregrown with amphibole) and fluorite (as individual crystals or filling microfractures mainly in the biotite). Secondary minerals are represented by clay-minerals, sericite and epidote.

MINERAL OCCURRENCES Until few years ago, all mineral occurrences in the southern Roraima were associated to the "Água Branca" suite and "Igarapé Azul" granite (CPRM 2000). However, the results of geological mapping and petrographic study in this work demonstrated that amethyst, columbite-tantalite and gold occurrences are related with three different granitic types.

In the northern area (NUAD), the highly deformed, showing quartz-vein related to shear zones, and hydrothermallized (muscovitization and tourmalinization) host rocks of the Anauá small gold mine (Faria et al. 1996) overprint the igneous features. In other two sites, there has been detected $\mathrm{Au}$ in alluvial sediments overlying Martins Pereira granitoid rocks basement. Despite the difficulty of recognizing the primary rocks, the host of mineralization shows composition, texture and age (1972 $\pm 7 \mathrm{Ma}$, zircon U-Pb SHRIMP, CPRM 2003) similar to the I-type Martins Pereira granitoid rocks. Furthermore, relationship among gold occurrences and S-type granites (e.g. Serra Dourada granite) is uncommom (e.g. Neiva 2000).

In the SUAD, several columbite-tantalite occurrences in alluvial sediments have been described (CPRM 2000); all of them are located in the Igarapé Azul granite region. The main $\mathrm{Nb}-\mathrm{Ta}$ occurrences are related to the central Vila Catarina facies, which is characterized by pegmatites and alluvial fans with conglomeratic levels $(0.5 \mathrm{~m}$ in average) showing angular and subrounded fragments of columbite-tantalite ranging from $80 \mathrm{~mm}$ to $0.2 \mathrm{~mm}$ in length. Also in this area, the amethyst crystals occur in regular veins, pegmatites or in stockwork structures, hosted by the A-type
Moderna granitoid rocks. According to CPRM (2000) this amethyst mineralization probably has an epithermal origin.

SUMMARY AND CONCLUDING REMARKS Geological mapping and petrographic studies of granitoid rocks in the north and south areas of the Uatumã-Anauá domain provide new insights in the geologic framework of the central portion of Guyana Shield (Fig. 1), including mineralization occurrence relationship, and implications for the tectonic evolution.

The Martins Pereira and Serra Dourada granites in NUAD are characterized by penetrative deformation and dextral shear zones associated with NE-SW to E$\mathrm{W}$-trendings, and both are associated with metavolcano-sedimentary covers and older basement inliers (Anauá Complex and Cauarane Group). The S-type Serra Dourada granite suggests, at least locally, a widespread anatexis of dominant sedimentary sources in this region.

In the Martins Pereira granitoid rocks, the petrographic similarities point out that the granitoid rock host-rocks (monzogranites and granodiorites) and the biotite-bearing enclaves (tonalites) are cogenetic. The origin of leucogranitic blobs is not well understood, but two explanations can be envisaged: a) highly fractionated types from Martins Pereira calc-alkaline association, or b) new granitic magmas from small-scale remelting of Martins Pereira granitoid rocks (local anatexis).

The tectonic evolution is yet debatable, but the relationship of the NUAD granitoid rocks with the Anauá Arc (Faria et al. 2002) is possible, due mainly the geographic aspects and features of ntrusion. The I-type calc-alkaline and S-type granites chemistry and ages suggest that they could be related to the final stages, or after, of the Anauá Arc $(2.03 \mathrm{Ga})$ development. The $\sim 60$ Ma elapsed time among Anauá arc formation and the emplacement of the Martins Pereira-Serra Dourada granitoid rocks point out a late(?)-collisional event at 1.97-1.96 Ga in the southeastern Roraima.

On theotherhand, the SUAD area is characterized by only undeformed calc-alkaline Caroebe and Igarapé Azul granites (Água Branca suite) and local coeval volcanic rocks, but no arc-related metavolcano-sedimentary rocks and low-K calc-alkaline granitoid rocks are recorded. A petrogenetic evolution following fractional crystallization process was suggested by Oliveira et al. (1996) for the Água Branca suite, however, at least locally, other petrogenetic processes can be involved in the genesis of the Caroebe granite (e.g. partial melting, magma mixing or assimilation fractional crystallization).

The magma mixing hypothesis for the Alto Alegre facies of the Caroebe granite is based on field observations, where two end-members, represented by felsic monzogranite and hornblende diorite-tonalite, produced an intermediate homogeneous granodioritic member (hybrid magma). However, some authors (e.g. Chappell and McCulloch 1990, Chappell 1996) argue 
that this petrogenetic process is related only to the small-scale granite generation and do not support large bodies generation due to the large viscosity contrast between two magmas of contrasting compositions that inhibit the mixing. According to them, magma mixing is limited in most granitoid rock evolution. Magma mixing is an important petrogenetic model for granitoid rocks generation, but only mixing events could be recorded in the pluton, generating local hybrid rocks.

Other authors believe that large granitic batholiths are produced mainly by magma mixing process, such as the Itaporanga batholith in northeastern Brazil (Mariano and Sial 1990) and H-type granitoid rocks in Spain (Castro et al. 1990, 1991). They are based on the geochemical and experimental constraints mainly observed in volcanic rocks (e.g. Turner and Campbell 1986, Gourgaud et al. 1989) and their application to plutonic rocks (e.g. Blake and Koyaguchi 1991). According to Blake and Koyaguchi (1991), if hybrid volcanic magmas are produced in the magma chambers (that are the precursors of plutonic rocks) then, the plutonic analogues of these same chambers should contain hybrid facies. However, likewise the volcanic types, areas of hybrid rock within pluton could record mixing events related to the intermittent generations of batch melts. Thus, a geochemical study in the Caroebe granite is necessary for a better evaluation of the petrogenetic model.

The Igarapé Azul granite also shows calc-alkaline affinity (Almeida and Macambira 2003), but it is almost restrict to felsic monzogranites types, which are characterized by homogeneous texture. These granitoid rocks show similar compositional field of the crustal granite origin and petrographic features to felsic granites occurring as lenses and blobs in the Martins Pereira granite (e.g. monzogranitic composition, textural homogeneity, low modal content of mafic minerals, biotite and late muscovite as the varietal minerals, and epidote and opaque minerals as the main accessory minerals).

The magmatic flow and shape of granitic bodies with NE-SW to E-W-trends observed in the Igarapé Azul and Caroebe granites suggest that the emplacement was probably structurally-controlled by older lineaments, such as observed in the Martins Pereira granitoid rocks.

The two generations of A-type granites which are widespread in UAD, are related to a post-orogenic $(1.87 \mathrm{Ga})$ to anorogenic $(1.81 \mathrm{Ga})$ setting respectively, and mark the tectonic stability period in the southeastern Roraima. The emplacement of these A-types granites has E-W and NW-SE-trending structural-control, filling mainly brittle structures.

Finally, the relationship between mineralization and the granitoid rock hosts in the UAD, as a whole, opens new metaloctec perspectives, emphasizing the mineral potential of this region for gold (Martins Pereira granitoid rocks), columbite-tantalite (mainly in the central facies of Igarapé Azul granite) and amethyste (Moderna granite, pegmatite).

Acknowledgments Special thanks to M.S.G. de Faria (MJ-DPF-Manaus), N. J. Reis, S. S. Pinheiro and R. Luzardo (Geological Survey of Brazil) for geological discussions. The authors are grateful also to the Geological Survey of Brazil (CPRM) and Federal University of Pará (UFPA) for the support to this research. Thanks also to the three anonymous referees for suggestions to the manuscript.

\section{References}

Almeida M.E. \& Macambira M.J.B. 2003. Aspectos geológicos e litoquímicos dos granitóides cálcioalcalinos Paleoproterozóicos do sudeste de Roraima. In: SBGq, Cong. Brasil. Geoq., 9, Anais, p. 775-778.

Almeida M.E., Macambira M.J.B., Faria M.S.G. de. 2002. A Granitogênese Paleoproterozóica do Sul de Roraima. In: SBG, Cong. Bras. Geol., 41, Anais, p 434.

Araújo Neto H. \& Moreira H.L. 1976. Projeto Estanho do Abonari. Manaus, Convênio DNPM/CPRM, Relatório Final. 2v.

Berrangé J.P. 1972. The Tectonic/Geological Map of Southern Guyana. In: Ministerio de Minas e Hidrocarburos, Conferencia Geológica Inter-Guayanas, 9, Boletin de Geología, Publicacion Especial, v. 6, p.161-174.

Blake S. \& Koyaguchi T. 1991. Insights on the magma mixing model from volcanic rocks. In: J. Didier \& B. Barbarin (eds.) Enclaves and granite petrology. Elsevier, p. 403-413.

Castro A., de la Rosa J.D., Stephens W.E. 1990. Magma mixing in the subvolcanic environment. Petrology of the Gerena interaction zone near Seville, Spain. Contrib. Mineral. Petrol., 105:9-26.
Castro A., Moreno-Ventas I., de la Rosa J.D. 1991. H-type (Hybrid) granitoid rocks: A proposed revision of the granite-type classification and nomenclature. Earth Science Rev., 31:237-253.

Chappell B.W. 1996. Magma mixing and the production of compositional variation within granite suites: evidence from the granites of southeastern Australia. Journ. Petrol., 37:449-470.

Chappell B.W. \& McCulloch M.T. 1990. Possible mixed source rocks in the Bega Batholith: constraints provided by combined chemical and isotopic studies. Abst. Geol. Soc. Australia, 27:17.

Costi H.T., Dall'Agnol R., Moura C.A.V. 2000. Geology and $\mathrm{Pb}-\mathrm{Pb}$ geochronology of Paleoproterozoic volcanic and granitic rocks of the Pitinga Province, Amazonian craton, northern Brazil. Intern. Geol. Rev., 42:832-849.

Costi H.T., Santiago A.F., Pinheiro S.S. 1984. Projeto Uatumã-Jatapu. Manaus, CPRM, Relatório Final, 133p.

CPRM. 1999. Programa Levantamentos Geológicos Básicos do Brasil. Roraima Central, Folhas NA.20-X-B e NA.20$X-D$ (integrais), NA.20-X-A, NA.20-X-C, NA.21-V-A e NA.21-V-C (parciais). Escala 1:500.000. Estado de 
Roraima. Manaus, CPRM, 166 p, CD-ROM.

CPRM. 2000. Programa Levantamentos Geológicos Básicos do Brasil. Caracaraí, Folhas NA.20-Z-B e NA.20-Z-D (integrais), NA.20-Z-A, NA.21-Y-A, NA.20-Z-C e NA.21$Y$-C (parciais). Escala 1:500.000. Estado de Roraima. Manaus, CPRM, 157 p. CD-ROM.

CPRM. 2003. Geologia, Tectônica e Recursos Minerais do Brasil: sistema de informações geográficas - SIG. Rio de Janeiro, CPRM, Programa Levantamentos Geológicos Básicos do Brasil, Mapas Escala 1:2.500.000, 4 CDs

CPRM. 2006. Geologia e Recursos Minerais do Estado do Amazonas. Manaus, CPRM/CIAMA-AM, Programa Integração, Atualização e Difusão de Dados da Geologia do Brasil - Subprograma Mapas Geológicos Estaduais, Escala 1:1.000.000. Texto explicativo, 148p, CD ROM.

Faria M.S.G. de, Luzardo R., Pinheiro S. da S. 1999. Litoquímica e petrogênese do Granito Igarapé Azul. In: SBG, Simp. Geol. Amaz., 6, Anais, p. 577-580.

Faria M.S.G. de, Oliveira M.J.R., Luzardo R, Pinheiro S. da S. 1996. Garimpo do Anauá, Sudeste do Estado de Roraima: dados preliminares sobre ocorrência aurífera associada à zona de cisalhamento. In: SBG, Cong. Bras. Geol., 39, Anais, v. 3 p. 316-319.

Faria M.S.G. de, Almeida M.E., Santos J.O.S. dos, Chemale Jr. F. 2003. Evolução Geológica da Região do Alto Rio Anauá - Roraima. In: SBG, Simp. Geol. Amaz., 8, Anais, CD-ROM.

Faria M.S.G. de, Santos J.O.S.dos, Luzardo R., Hartmann L.A., McNaughton N.J. 2002. The oldest island arc of Roraima State, Brazil - 2.03 Ga: zircon SHRIMP U-Pb geochronology of Anauá Complex. In: SBG, Congr. Brasil. Geol., 41, Anais, p. 306.

Gaudette H.E., Olszewski W.J. Jr., Santos J.O.S. dos. 1996. Geochronology of Precambriam rocks from the northern part of Guiana Shield, State of Roraima, Brazil. Journ. South Am. Earth Sci., 9:183-195.

Gibbs A.K. \& Barron C.N. 1993. The geology of the Guyana Shield. Oxford University Press, Oxford, N.York, 245p.

Gourgaud A., Fichaut M., Joron J. L. 1989. Magmatology of Mt. Pelee (Martinique, F.W.I.). I: Magma mixing and triggering of the 1902 and 1929 Pelean nuees ardentes. J. Volc. Geotherm. Res., 38:143-169.

Jorge-João X.S., Santos C.A., Provost A. 1985. Magmatismo adamelítico Água Branca (Folha Rio Ma puera, NW do Estado do Pará). In: SBG, Simp. Geol. Amaz., 2, Anais, v.2, p. 93-109.

Lameyre J. \& Bonin B. 1991. Granites in the main plutonic series. In: J. Didier \& B. Barbarin (eds.) Enclaves and Granite Petrology. Development in Petrology, v.13, p.317.

Lameyre J. \& Bowden P. 1982. Plutonic rock type series: discrimination of various granitoid rocks series and related rocks. J. Volc. Geotherm. Res., 14:169-186.

Macambira M.J.B., Almeida M.E., Santos L.S. 2002. Idade de Zircão das Vulcânicas Iricoumé do Sudeste de Roraima: contribuição para a redefinição do Supergrupo Uatumã. In: SBG, Simpósio Sobre Vulcanismo e Ambientes Associados, 2, Anais, p. 22.

Mariano G. \& Sial A.N. 1990. Coexistence and Mixing of Magmas in the Late Precambrian Itaporanga Batholith,
State of Paraiba, Northeastern Brazil. Rev. Bras. Geoc., 20(1-4):101-110.

Neiva A.M.R. 2000. Comparison between Portuguese granites associated with $\mathrm{Sn}-\mathrm{W}$ mineralizations and with $\mathrm{Au}$ mineralization. In: SBG, Intern. Geol. Cong., 31, Abstrac Vol., CD-ROM.

Oliveira M.J.R., Almeida M.E., Luzardo R., Faria M.S.G. de. 1996. Litogeoquímica da Suíte Intrusiva Água Branca SE de Roraima. In: SBG, Congr. Bras. Geol., 39, Anais, v.2, p. 213-216 .

Passchier C.W. \& Trouw R.A.J. 1996. Microtectonics. Springer Verlag, London, 326p.

Reis N.R. \& Fraga L.M.B. 1996. Vulcanismo Surumu - Estado de Roraima: Caracterização de seu comportamento químico à luz de novos dados. In: SBG, Congr. Bras. Geol., 39, Anais, v. 2, p. 88-90 .

Reis N.J. \& Fraga L.M.B. 2000. Geological and tectonic framework of Roraima State, Guyana Shield - An overview. In: SBG, Intern. Geol. Cong., 31, Abstract Vol., Gen. Simp. 9, CD-ROM.

Reis N.R., Faria M.S.G. de, Fraga L.M.B., Haddad R.C. 2000. Orosirian calc-alkaline volcanism from eastern portion of Roraima State - Amazon Craton. Rev. Bras. Geoc. 30(3):380-383.

Reis N.J., Fraga L.M., Faria M.S.G. de, Almeida M.E. 2003. Geologia do Estado de Roraima. Géologie de la France, 2-3:71-84.

Santos, J.O.S. dos, Hartmann, L.A., Gaudette, H.E., Groves, D.I., McNaughton, N.J., Fletcher, I.R. 2000. A new understanding of the provinces of the Amazon Craton based on integration of field mapping and $\mathrm{U}-\mathrm{Pb}$ and $\mathrm{Sm}-$ Nd geochronology. Gond. Res. 3(4):453-488.

Santos J.O.S. dos, Silva L.C., Faria M.S.G. de, Macambira, M.J.B. 1997. Pb-Pb single crystal, evaporation isotopic study on the post-tectonic, sub-alkalic, A-type Moderna granite, Mapuera intrusive suite, State of Roraima, northern Brazil. In: SBG, Symposium of Granites and Associated Mineralizations, 2, Ext.Abstract, p.273-275.

Streckeisen A.C. 1976. To each plutonic rock its proper name. Earth Sci. Rev., 12:1-33.

TassinariC.C.G.\&MacambiraM.J.B. 1999. Geochronological Provinces of the Amazonian Craton. Episodes, 22(3):174182.

Turner J.S. \& Campbell I.H. 1986. Convection and mixing in magma chambers. Earth Sci. Rev., 23:255-52.

Veiga Jr. J.P., Nunes A.C.B., Souza E.C. de, Santos J.O.S. dos, Amaral J.E., Pessoa M.R., Souza S.A. de S. 1979. Projeto Sulfetos do Uatumã. Manaus, DNPM/CPRM, Relatório Final, $6 \mathrm{v}$.

Vernon R.H., Etheridge M.A., Wall V.J. 1988. Shape and microstructure of microgranitoid rock enclaves: indicators of magma mingling and flow. Lithos, 22:1-11.

White A.J.R. 1992. Granite Handbook: description, genesis and some associated ore deposits. Short course, SBG, São Paulo. 49p.

Manuscrito AE-029/2006 Submetido em 25 de julho de 2006 Aceito em 13 de junho de 2007 